\title{
Transcriptomic comparison of communally reared wild, domesticated and hybrid Atlantic salmon fry under stress and control conditions
}

\author{
Beatrix Bicskei ${ }^{1}$, John B. Taggart ${ }^{1}$, James E. Bron ${ }^{1}$ and Kevin A. Glover ${ }^{2,3^{*}}$ (1)
}

\begin{abstract}
Background: Domestication is the process by which organisms become adapted to the human-controlled environment. Since the selection pressures that act upon cultured and natural populations differ, adaptations that favour life in the domesticated environment are unlikely to be advantageous in the wild. Elucidation of the differences between wild and domesticated Atlantic salmon may provide insights into some of the genomic changes occurring during domestication, and, help to predict the evolutionary consequences of farmed salmon escapees interbreeding with wild conspecifics. In this study the transcriptome of the offspring of wild and domesticated Atlantic salmon were compared using a common-garden experiment under standard hatchery conditions and in response to an applied crowding stressor.
\end{abstract}

Results: Transcriptomic differences between wild and domesticated crosses were largely consistent between the control and stress conditions, and included down-regulation of environmental information processing, immune and nervous system pathways and up-regulation of genetic information processing, carbohydrate metabolism, lipid metabolism and digestive and endocrine system pathways in the domesticated fish relative to their wild counterparts, likely reflective of different selection pressures acting in wild and cultured populations. Many stress responsive functions were also shared between crosses and included down-regulation of cellular processes and genetic information processing and up-regulation of some metabolic pathways, lipid and energy in particular. The latter may be indicative of mobilization and reallocation of energy resources in response to stress. However, functional analysis indicated that a number of pathways behave differently between domesticated and wild salmon in response to stress. Reciprocal F1 hybrids permitted investigation of inheritance patterns that govern transcriptomic differences between these genetically divergent crosses. Additivity and maternal dominance accounted for approximately 42 and $25 \%$ of all differences under control conditions for both hybrids respectively. However, the inheritance of genes differentially expressed between crosses under stress was less consistent between reciprocal hybrids, potentially reflecting maternal environmental effects.

(Continued on next page)

\footnotetext{
* Correspondence: kevin.glover@hi.no

${ }^{2}$ Institute of Marine Research, Bergen, Norway

${ }^{3}$ Department of Biology, University of Bergen, Bergen, Norway

Full list of author information is available at the end of the article
}

(c) The Author(s). 2020 Open Access This article is licensed under a Creative Commons Attribution 4.0 International License, which permits use, sharing, adaptation, distribution and reproduction in any medium or format, as long as you give appropriate credit to the original author(s) and the source, provide a link to the Creative Commons licence, and indicate if changes were made. The images or other third party material in this article are included in the article's Creative Commons licence, unless indicated otherwise in a credit line to the material. If material is not included in the article's Creative Commons licence and your intended use is not permitted by statutory regulation or exceeds the permitted use, you will need to obtain permission directly from the copyright holder. To view a copy of this licence, visit http://creativecommons.org/licenses/by/4.0/ The Creative Commons Public Domain Dedication waiver (http://creativecommons.org/publicdomain/zero/1.0/) applies to the data made available in this article, unless otherwise stated in a credit line to the data. 
(Continued from previous page)

Conclusion: We conclude that there are transcriptomic differences between the domesticated and wild salmon strains studied here, reflecting the different selection pressures operating on them. Our results indicate that stress may affect certain biological functions differently in wild, domesticated and hybrid crosses and these should be further investigated.

Keywords: Atlantic salmon, Salmo salar, Domestication, Transcriptome, Microarray, Stress, Farmed escapee, Genetic interaction

\section{Background}

Domestication is possible because some organisms can adapt to the human-controlled environment. The highly contrasting environments that wild and domesticated animals experience thus exert different selection pressures which may in turn promote habitat-specific adaptations [1, 2]. Domestication is beneficial to humans, and advances are achieved via both deliberate directional selection for desired traits, and through inadvertent selection for traits that improve productivity in the culture environment.

In the case of the Atlantic salmon, Salmo salar L., economically important production traits including increased growth, late maturation, greater disease resistance and improved flesh quality have been selected for up to approximately 15 generations [3, 4], and this species is now regarded as one of the most domesticated finfish species globally [5]. Simultaneously, unintentional selection to the domestic environment will have occurred through relaxed natural selection and coselection of traits via genetic linkage and adaptation to the human-controlled environment. For example, predator-avoidance behaviour, that is essential to survival in the wild but insignificant in aquaculture, has changed during domestication of Atlantic salmon even though it has not been selected for [6-9]. Also, reduced survival of offspring of domesticated salmon has been demonstrated in the natural environment [10-13]. This is of concern given that introgression of domesticated salmon escapees in wild populations has been demonstrated in several regions where aquaculture and wild populations co-exist [14-16].

Because the fitness consequences of genetically controlled traits shift during domestication, the optimal investment of resources differs between farm and wild niches. According to resource-allocation theory, since resources available for a given individual are limited, the increased energy demands of one trait may have to be counterbalanced by reducing energy allocation to other, at least momentarily, less important traits. For example, growth is often under strong directional selection in domesticated populations, including Atlantic salmon [17-21]. At the same time, immune function is both necessary and highly energy demanding. Therefore, there is a possible trade-off between growth and immune function as has been proposed for domesticated animals in general [22].

Due to the protected environment of captivity and reliance upon humans to meet key needs, reduced environmental awareness is likely to be a consequence of domestication. This may occur through the decline of information acquisition and transmission systems, such as sensory organs and synaptic activity. Environmental awareness is an evolutionarily highly important trait in the wild, but its reduction is likely to be beneficial for domesticated species in culture through reduction of stress [23]. The effect of domestication on complex traits can be difficult to disentangle such that the activity of traits with multiple biological functions may be enhanced in one species, due to a certain beneficial function, but decreased in another, due to a different function that bears more weight for that organism. As a result, and in contrast to the hypothesized benefit of reduced synaptic activity in domesticated animals, enhanced excitatory synaptic plasticity and its contribution through enhanced memory and learning to effective interaction with humans has been proposed in dogs (Canis familiaris) [24].

Response to stimuli, including stress, is contextdependent and among other factors it is influenced by variability in individuals' experience of the stimulus [25]. Wild and domesticated Atlantic salmon are adapted to different rearing environments and in addition to a wide range of traits [26], their stress responsiveness also differs [19]. Because stress disturbs homeostasis and its restoration is energy demanding, increased stressresponsiveness requires an increased allocation of available resources. To cover this demand, energy is generally directed away from functions that are non-vital and have high energetic costs associated with them, such as growth and reproduction [25], necessitating a further trade-off under culture conditions.

Alteration of gene expression may provide a rapid and plastic response to stress [27, 28]. In addition, since changes in gene expression profiles over time may reflect evolutionary change [29], the study of gene expression is suitable for studying the process of domestication. Given that the Atlantic salmon has now undergone $~ 12-15$ 
generations of domestication selection, resulting in a wide range of genetic-based differences to wild salmon [26], this species represents a good model in which to investigate domesticated-driven changes in the transcriptome. Several previous studies have already utilised the key-attributes of this species [30-32], revealing domestication-driven changes that are likely to be lifestage dependent [33, 34].

The aim of the present study was to i) investigate transcriptomic patterns of wild, F1 hybrid and domesticated Atlantic salmon fry under control and acute stress conditions, ii) identify any existing strain-specific transcriptomic stress responses resulting from gene $\times$ family interactions and iii) determine the mode of heritability of the genes identified as differentially expressed between the three genetic groups under both control and stress conditions.

\section{Results}

\section{Expression data overview}

3D-PCA clustered the samples according to condition (stress / control) and genetic group (wild / reciprocal hybrids / domesticated) (Fig. 1). Pure wild and pure domesticated groups were found to be the most divergent, whereas reciprocal hybrids tended to be intermediate. Significantly however, the positioning of the reciprocal hybrid groups were indicative of their maternal origin, such that wild dam hybrids tended to be closer to pure wild group, while hybrids of domesticated dams clustered towards pure domesticated group (Fig. 1).
Statistical analysis (2-way ANOVA, FDR corrected $p<$ $0.05)$ revealed a number of differentially expressed transcripts among genetic groups and conditions, but no interaction between these two factors exceeded the statistical threshold (Fig. 2a). Separate analyses were performed i) comparing pure wild and domesticated groups only, and ii) considering all four genetic groups i.e. including reciprocal hybrids. Looking at the differential expression explained by genetic group (Fig. $2 \mathrm{~b}$ ), the majority of transcripts (2247) were common to both analyses. In contrast, despite 1377 differentially expressed transcripts being common to both analyses for the factor condition, inclusion of hybrids provided a substantial addition of 2864 unique transcripts (Fig. 2c).

\section{Functional analysis}

Functional analyses of the transcriptomic differences between domesticated and wild strains, as well as in response to stress were performed using two different software packages. Results are presented in Tables 1, 2 and 3.

Differences detected in domesticated origin fish relative to wild origin fish tended to be similar in category and direction under both control and stressed conditions. They included down-regulation of signal transduction and immune and nervous systems, up regulation of mRNA translation, carbohydrate metabolism and lipid metabolism and digestive system and both up and down regulation of some pathways of the endocrine system (Table 1). Some of the differentially expressed biological functions were represented by a smaller number of

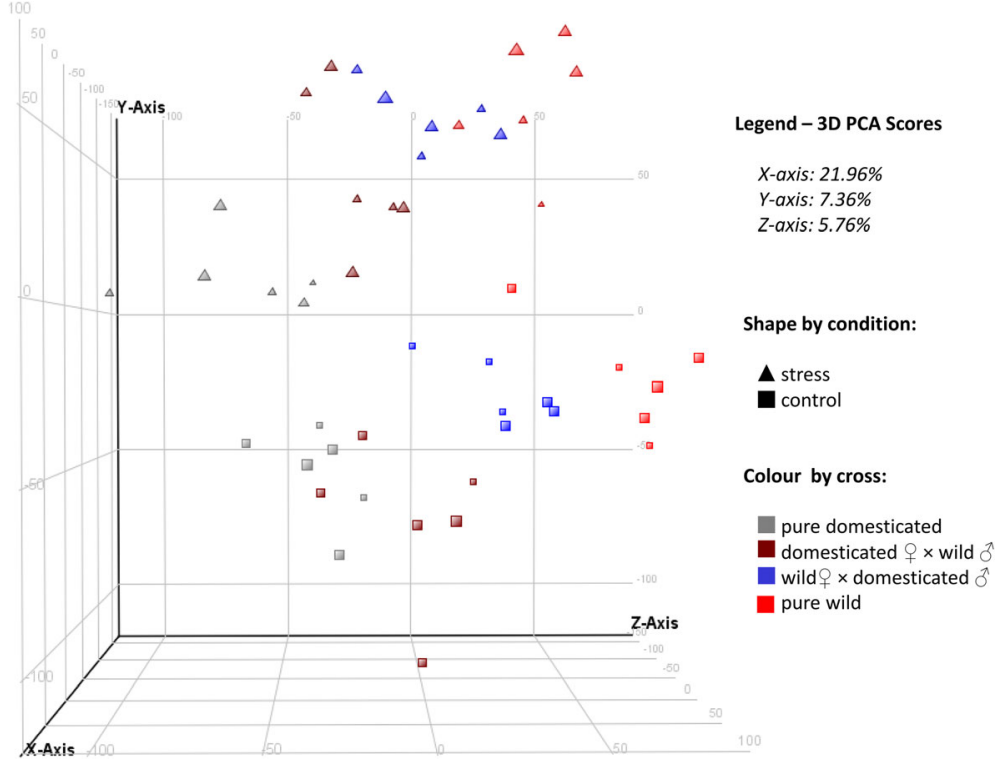

Fig. 1 A 3-D representation of the PCA performed on all transcripts that passed quality filtering. Samples are colour and shape coded by the experimental factors. Note the clear distinction between stress and control samples and the general tendency for clustering of samples by state. PCA was conducted on normalised data 

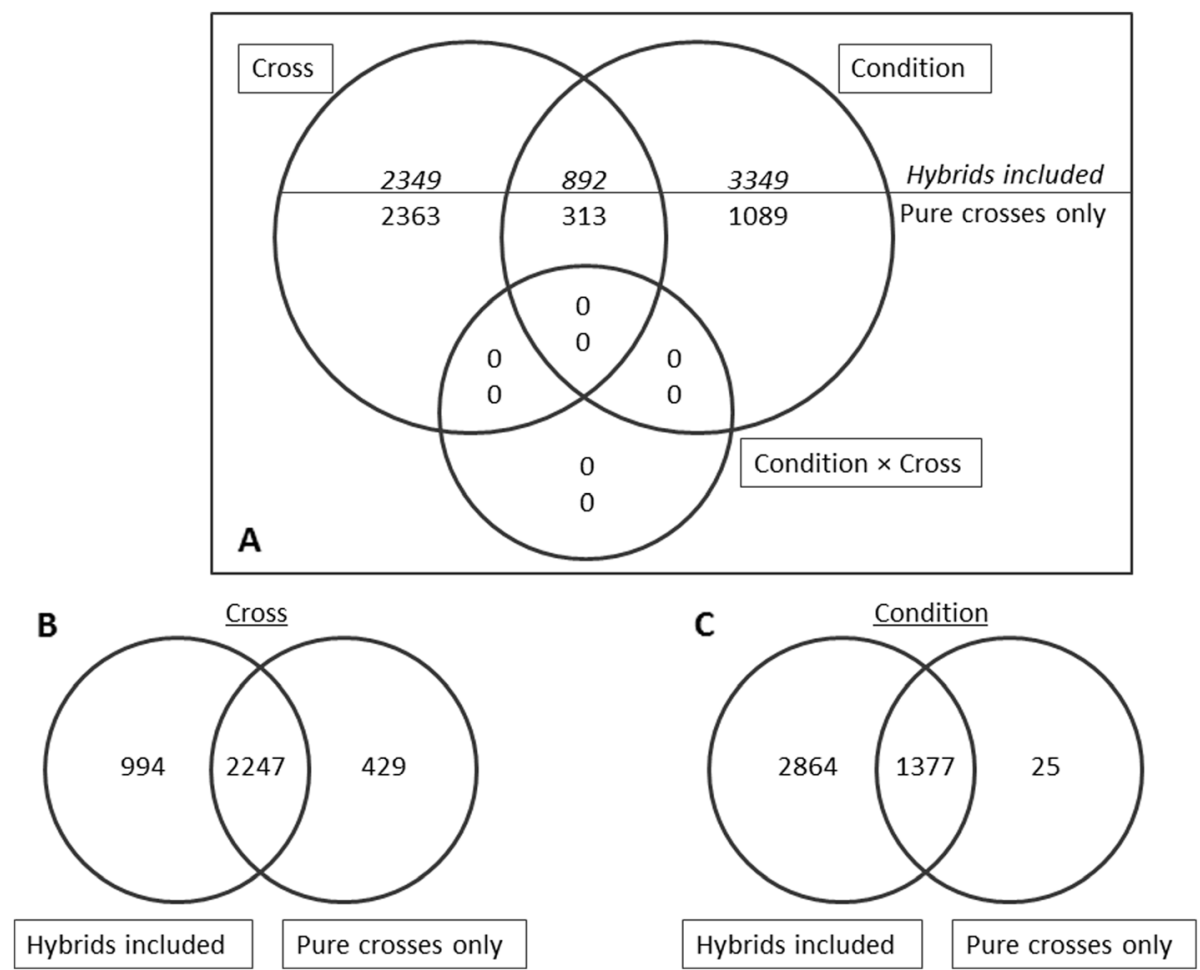

Fig. 2 A representation of the number of differentially expressed transcripts based on a 2-way ANOVA. a. Transcriptomic differences arising through variation between all crosses (WxW, WxD, DxW, DxD) conditions (stress and control) and the interaction of these two factors. The top numbers reflect statistics for all crosses including the hybrids, whereas the bottom numbers were generated by limiting the 2-way ANOVA to pure crosses only. $\mathbf{b}$. The common and unique differences in cross-specific expression with and without consideration of reciprocal hybrids. $\mathbf{c}$ The common and unique differences arising from exposure to stress vs control conditions and detected with and without consideration of hybrids

pathways under stress conditions, the most pronounced being the digestive system, as a consequence of protein and vitamin digestion and absorption and mineral absorption pathways only being significantly different under control conditions.

In contrast, pathways differentially expressed in stress relative to control state for wild and domesticated pure genetic groups were less consistent (Table 2). Common transcriptional responses to stress, applicable to both pure genetic groups, included down-regulation of cell growth and death and DNA replication and repair. In addition, up-regulated digestive and endocrine systems appeared to be characteristic of the wild stress response, whereas up-regulated signalling molecules and interaction pathways were only found in domesticated fish.

Pathways differentially expressed between the stress and control states for hybrids showed some variation according to the direction of the hybridisation (Table 3). Pathways that were consistent between both hybrids included down-regulation of cell growth and death, DNA replication and repair and up-regulation of carbohydrate and lipid metabolism in response to stress. In addition, up-regulation of signal transduction and nervous system pathways under stress appeared to be characteristic to
$\mathrm{D}+\mathrm{W} \widehat{\bigcirc}$ hybrids only. Also, up-regulated digestive and endocrine systems were represented by a larger number of pathways in this hybrid, than in the $\mathrm{W} \odot \mathrm{D}{ }^{\widehat{\lambda}}$ hybrid.

\section{Heritability}

Analysis of reciprocal hybrids allowed exploration of gene expression heritability. Additivity (38-46\%) accounted for most differential expression patterns detected among the four genetic groups, followed by maternal dominance (18-32\%) (Fig. 3, Table 4). On average $42 \%$ of the differentially expressed genes exhibited intermediate hybrid expression relative to the pure genetic groups. However, there was a greater difference in the relevance of additivity between the stressed reciprocal hybrids (38 and 46\%), than between controls (43 and $41 \%)$. The same was true for maternal dominance, with the percentages of differentially expressed genes in the reciprocal hybrids exhibiting this inheritance pattern under the control treatment being relatively consistent (26 and 24\%), whereas there was a greater difference between the hybrids under stress (32 and 18\%). For most comparisons, maternal dominance was more than double that of paternal dominance. However, in the case of the stressed $\mathrm{D}+\mathrm{W} \widehat{\sigma}$ hybrids, the difference was 
Table 1 Pathways found to be differentially expressed between wild and domesticated stocks under control and stress conditions by both gage and romer packages. The direction of change shown describes the expression of the pathway in the domesticated fish relative to wild counterparts. The terms "2D" and "Mixed" are used to describe pathways in which genes showed bidirectional change. "Genes" refers to the number of genes included in the gene set test

\begin{tabular}{|c|c|c|c|c|c|c|c|}
\hline \multirow[t]{2}{*}{ KEGG group } & \multirow[t]{2}{*}{ KEGG sub-group } & \multirow[t]{2}{*}{ Pathway } & \multirow[t]{2}{*}{ Genes } & \multicolumn{2}{|l|}{ Control } & \multicolumn{2}{|l|}{ Stress } \\
\hline & & & & gage & romer & gage & romer \\
\hline \multirow[t]{6}{*}{ Cellular Processes } & \multirow[t]{2}{*}{ Cell communication } & Focal adhesion & 98 & $2 \mathrm{D}$ & Down & $2 \mathrm{D}$ & Down \\
\hline & & Gap junction & 39 & & & $2 \mathrm{D}$ & Down \\
\hline & Cell growth and death & Cell cycle - yeast & 54 & Up & Up & Up & Up \\
\hline & \multirow[t]{3}{*}{ Transport and catabolism } & Phagosome & 76 & Down & Down/Mixed & Down & Down/Mixed \\
\hline & & Endocytosis & 105 & Down/2D & Down & Down/2D & Down \\
\hline & & Peroxisome & 54 & Up & Up & Up & Up \\
\hline \multirow{10}{*}{$\begin{array}{l}\text { Environmental } \\
\text { Information Processing }\end{array}$} & Membrane transport & $A B C$ transporters & 27 & & & Up & Mixed \\
\hline & \multirow[t]{6}{*}{ Signal transduction } & MAPK signaling pathway & 110 & $2 \mathrm{D}$ & Down & $2 \mathrm{D}$ & Down \\
\hline & & NF-kappa B signaling pathway & 64 & $2 \mathrm{D}$ & Down & & \\
\hline & & Jak-STAT signaling pathway & 56 & $2 \mathrm{D}$ & Down & & \\
\hline & & Calcium signaling pathway & 72 & $2 \mathrm{D}$ & Down & $2 \mathrm{D}$ & Down \\
\hline & & PI3K-Akt signaling pathway & 149 & $2 \mathrm{D}$ & Down/Mixed & Down/2D & Down \\
\hline & & VEGF signaling pathway & 28 & & & $2 \mathrm{D}$ & Down \\
\hline & \multirow[t]{3}{*}{$\begin{array}{l}\text { Signaling molecules and } \\
\text { interaction }\end{array}$} & $\begin{array}{l}\text { Cell adhesion molecules } \\
\text { (CAMs) }\end{array}$ & 64 & $2 \mathrm{D}$ & Down/Mixed & $2 \mathrm{D}$ & Down \\
\hline & & $\begin{array}{l}\text { Neuroactive ligand-receptor } \\
\text { interaction }\end{array}$ & 112 & Down/2D & Down & & \\
\hline & & $\begin{array}{l}\text { Cytokine-cytokine receptor } \\
\text { interaction }\end{array}$ & 94 & Down/2D & Down & $2 \mathrm{D}$ & Down \\
\hline \multirow{6}{*}{$\begin{array}{l}\text { Genetic Information } \\
\text { Processing }\end{array}$} & Replication and repair & DNA replication & 33 & & & Up & Up \\
\hline & \multirow[t]{2}{*}{ Transcription } & RNA polymerase & 27 & Up & Up & Up & Up \\
\hline & & Spliceosome & 109 & & & Up & Up \\
\hline & \multirow[t]{3}{*}{ Translation } & $\begin{array}{l}\text { Ribosome biogenesis in } \\
\text { eukaryotes }\end{array}$ & 64 & Up & Up & Up & Up/Mixed \\
\hline & & RNA transport & 111 & Up & Up & Up & Up/Mixed \\
\hline & & Ribosome & 118 & Up & Up/Mixed & Up & Up/Mixed \\
\hline \multirow[t]{11}{*}{ Metabolism } & Amino acid metabolism & $\begin{array}{l}\text { Arginine and proline } \\
\text { metabolism }\end{array}$ & 36 & Up & Up & & \\
\hline & \multirow[t]{4}{*}{ Carbohydrate metabolism } & $\begin{array}{l}\text { Amino sugar \& nucleotide } \\
\text { sugar metabolism }\end{array}$ & 35 & Up & Up/Mixed & Up & Up/Mixed \\
\hline & & Galactose metabolism & 16 & Up & Up/Mixed & Up & Up/Mixed \\
\hline & & $\begin{array}{l}\text { Fructose and mannose } \\
\text { metabolism }\end{array}$ & 19 & Up & Up/Mixed & Up & Up/Mixed \\
\hline & & Glycolysis / Gluconeogenesis & 30 & Up & Up/Mixed & & \\
\hline & \multirow[t]{4}{*}{ Lipid metabolism } & Sphingolipid metabolism & 21 & Up & Up & Up & Up \\
\hline & & $\begin{array}{l}\text { Biosynthesis of unsaturated } \\
\text { fatty acids }\end{array}$ & 15 & Up & Up/Mixed & Up & Up/Mixed \\
\hline & & Glycerolipid metabolism & 25 & Up & Up/Mixed & & \\
\hline & & Primary bile acid biosynthesis & 12 & Up & Up/Mixed & Up & Up/Mixed \\
\hline & Nucleotide metabolism & Pyrimidine metabolism & 73 & Up & Up/Mixed & Up & Up \\
\hline & $\begin{array}{l}\text { Xenobiotics biodegradation } \\
\text { and metabolism }\end{array}$ & $\begin{array}{l}\text { Drug metabolism - cytochrome } \\
\text { P450 }\end{array}$ & 11 & Down & Down/Mixed & Down/2D & Down/Mixed \\
\hline Organismal Systems & Circulatory system & $\begin{array}{l}\text { Vascular smooth muscle } \\
\text { contraction }\end{array}$ & 55 & $2 \mathrm{D}$ & Down & Down/2D & Down \\
\hline
\end{tabular}


Table 1 Pathways found to be differentially expressed between wild and domesticated stocks under control and stress conditions by both gage and romer packages. The direction of change shown describes the expression of the pathway in the domesticated fish relative to wild counterparts. The terms "2D" and "Mixed" are used to describe pathways in which genes showed bidirectional change. "Genes" refers to the number of genes included in the gene set test (Continued)

\begin{tabular}{|c|c|c|c|c|c|c|c|}
\hline \multirow[t]{2}{*}{ KEGG group } & \multirow[t]{2}{*}{ KEGG sub-group } & \multirow[t]{2}{*}{ Pathway } & \multirow[t]{2}{*}{ Genes } & \multicolumn{2}{|l|}{ Control } & \multicolumn{2}{|l|}{ Stress } \\
\hline & & & & gage & romer & gage & romer \\
\hline & \multirow[t]{2}{*}{ Development } & Osteoclast differentiation & 69 & $2 \mathrm{D}$ & Down & $2 \mathrm{D}$ & Down \\
\hline & & Axon guidance & 52 & Down/2D & Down & & \\
\hline & \multirow[t]{6}{*}{ Digestive system } & Protein digestion and absorption & 40 & $2 \mathrm{D}$ & Mixed & & \\
\hline & & Vitamin digestion and absorption & 17 & $2 \mathrm{D}$ & Up/Mixed & & \\
\hline & & Mineral absorption & 25 & Up & Up/Mixed & & \\
\hline & & Fat digestion and absorption & 19 & Up & Up/Mixed & Up & Up/Mixed \\
\hline & & Bile secretion & 39 & Up/2D & Up/Mixed & Up/2D & Up \\
\hline & & Salivary secretion & 32 & & & Down/2D & Down \\
\hline & \multirow[t]{4}{*}{ Endocrine system } & Ovarian steroidogenesis & 22 & $2 \mathrm{D}$ & Down & $2 \mathrm{D}$ & Down \\
\hline & & Thyroid hormone synthesis & 33 & $2 \mathrm{D}$ & Up/Mixed & & \\
\hline & & PPAR signaling pathway & 42 & Up & Up & & \\
\hline & & Insulin secretion & 37 & & & $2 \mathrm{D}$ & Down \\
\hline & Environmental adaptation & Circadian entrainment & 45 & $2 \mathrm{D}$ & Down & Down/2D & Down \\
\hline & \multirow[t]{7}{*}{ Immune system } & T cell receptor signaling pathway & 61 & $2 \mathrm{D}$ & Down & & \\
\hline & & Fc epsilon RI signaling pathway & 29 & $2 \mathrm{D}$ & Down & $2 \mathrm{D}$ & Down/Mixed \\
\hline & & B cell receptor signaling pathway & 39 & $2 \mathrm{D}$ & Down & Down/2D & Down \\
\hline & & $\begin{array}{l}\text { Complement and coagulation } \\
\text { cascades }\end{array}$ & 56 & Down & Down/Mixed & Down & Down/Mixed \\
\hline & & Hematopoietic cell lineage & 38 & Down/2D & Down/Mixed & Down & Down \\
\hline & & Chemokine signaling pathway & 88 & Down/2D & Down/Mixed & Down/2D & Down/Mixed \\
\hline & & $\begin{array}{l}\text { Natural killer cell mediated } \\
\text { cytotoxicity }\end{array}$ & 40 & Down/2D & Down/Mixed & Down/2D & Down \\
\hline & \multirow[t]{4}{*}{ Nervous system } & Glutamatergic synapse & 50 & $2 \mathrm{D}$ & Down & Down/2D & Down \\
\hline & & Synaptic vesicle cycle & 35 & Down & Down & & \\
\hline & & Serotonergic synapse & 49 & Down & Down & Down & Down \\
\hline & & $\begin{array}{l}\text { Retrograde endocannabinoid } \\
\text { signaling }\end{array}$ & 46 & & & $2 \mathrm{D}$ & Down \\
\hline & Sensory system & Phototransduction & 14 & Down & Down & & \\
\hline
\end{tabular}

considerably smaller; paternal and maternal dominance accounting for 15 and $18 \%$ of the differentially expressed genes respectively. There were more pronounced maternal effects detected in $\mathrm{W}+\mathrm{D} \hat{\bigcirc}$ hybrids $\mathrm{cf} . \mathrm{D}+\mathrm{W} \hat{\sigma}$ hybrids at the expense of additivity under stress conditions, suggesting that the genes responsible for the imbalance are specifically wild maternal and not just maternal dominant. Under stress conditions, genes that were wild dominant in the $\mathrm{W}+\mathrm{D} \widehat{\circ}$ hybrids, and were also wild dominant (or additive) in the $\mathrm{D} \odot \mathrm{W} \widehat{\sigma}$ hybrids were considerably more abundant than genes that were domesticated dominant in the $\mathrm{D} \odot \mathrm{W} \widehat{0}$ hybrids and were also domesticated dominant (or additive) in the $\mathrm{W}+\mathrm{D} \delta$ hybrids (34 vs 9 genes). Only seven of these genes were differentially expressed under control conditions, where four of them showed maternal dominance (Additional file 3). The expression of the nominal wild dominant

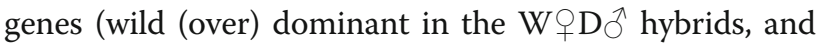

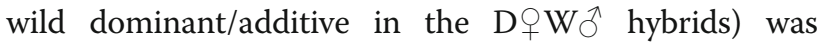
more consistent in the domesticated crosses than in the wild crosses under stress (Fig. 4). The products of many of the genes were enzymes involved in metabolism, in particular lipid and energy metabolisms.

\section{Discussion}

Atlantic salmon have been selectively bred since the early 1970s, and as a result, wild and domesticated Atlantic salmon populations now display genetic differences to each other in a wide range of traits [26]. Therefore, Atlantic salmon provides a good model in 
Table 2 Pathways found to be differentially expressed between control and stress conditions in pure wild and domesticated stocks by both gage and romer packages. The direction of change shown describes the expression of the pathway in the stressed fish relative to the control state. The terms "2D" and "Mixed" are used to describe pathways in which genes showed bidirectional change. "Genes" refers to the number of genes included in the gene set test

\begin{tabular}{|c|c|c|c|c|c|c|c|}
\hline \multirow[t]{2}{*}{ KEGG group } & \multirow[t]{2}{*}{ KEGG sub-group } & \multirow[t]{2}{*}{ Pathway } & \multirow[t]{2}{*}{ Genes } & \multicolumn{2}{|l|}{ Wild } & \multicolumn{2}{|c|}{ Domesticated } \\
\hline & & & & gage & romer & gage & romer \\
\hline \multirow[t]{5}{*}{ Cellular Processes } & Cell communication & Gap junction & 39 & & & $2 \mathrm{D}$ & Down \\
\hline & Cell growth and death & Cell cycle & 88 & Down & Down/Mixed & Down & Down/Mixed \\
\hline & & Cell cycle - yeast & 54 & Down & Down/Mixed & Down & Down/Mixed \\
\hline & & Meiosis - yeast & 41 & Down & Down/Mixed & Down & Down/Mixed \\
\hline & Transport and catabolism & Endocytosis & 105 & & & $2 \mathrm{D}$ & Up \\
\hline \multirow{3}{*}{$\begin{array}{l}\text { Environmental Information } \\
\text { Processing }\end{array}$} & Signal transduction & Hippo signaling pathway - fly & 29 & $2 \mathrm{D}$ & Down & $2 \mathrm{D}$ & Down \\
\hline & $\begin{array}{l}\text { Signaling molecules and } \\
\text { interaction }\end{array}$ & $\begin{array}{l}\text { Cytokine-cytokine receptor } \\
\text { interaction }\end{array}$ & 94 & & & $2 \mathrm{D}$ & Up \\
\hline & & $\begin{array}{l}\text { Neuroactive ligand-receptor } \\
\text { interaction }\end{array}$ & 112 & & & Up/2D & Up \\
\hline \multirow[t]{9}{*}{$\begin{array}{l}\text { Genetic Information } \\
\text { Processing }\end{array}$} & $\begin{array}{l}\text { Folding, sorting and } \\
\text { degradation }\end{array}$ & Proteasome & 40 & Down & Down & Down & Down/Mixed \\
\hline & Replication and repair & Base excision repair & 28 & Down & Down/Mixed & Down & Down/Mixed \\
\hline & & DNA replication & 33 & Down & Down/Mixed & Down & Down/Mixed \\
\hline & & Fanconi anemia pathway & 35 & Down & Down/Mixed & & \\
\hline & & Homologous recombination & 20 & Down & Down/Mixed & Down & Down \\
\hline & & Mismatch repair & 18 & Down & Down/Mixed & Down & Down/Mixed \\
\hline & & Nucleotide excision repair & 35 & Down & Down/Mixed & & \\
\hline & Transcription & Spliceosome & 109 & Down & Down & Down & Down \\
\hline & Translation & Ribosome biogenesis in eukaryotes & 64 & Down & Down/Mixed & Down & Down/Mixed \\
\hline \multirow[t]{6}{*}{ Metabolism } & Carbohydrate metabolism & Glycolysis / Gluconeogenesis & 30 & Up & Up/Mixed & & \\
\hline & Energy metabolism & Oxidative phosphorylation & 105 & Up & Up & Up & Up \\
\hline & $\begin{array}{l}\text { Metabolism of cofactors and } \\
\text { vitamins }\end{array}$ & $\begin{array}{l}\text { Nicotinate and nicotinamide } \\
\text { metabolism }\end{array}$ & 12 & Up & Up/Mixed & & \\
\hline & Nucleotide metabolism & Purine metabolism & 104 & & & Down & Down/Mixed \\
\hline & & Pyrimidine metabolism & 73 & Down & Down/Mixed & Down & Down/Mixed \\
\hline & Lipid metabolism & Fatty acid degradation & 24 & Up & Up & & \\
\hline \multirow[t]{14}{*}{ Organismal Systems } & Circulatory system & Cardiac muscle contraction & 41 & Up & Up & & \\
\hline & Digestive system & $\begin{array}{l}\text { Carbohydrate digestion and } \\
\text { absorption }\end{array}$ & 15 & Up & Up & & \\
\hline & & Fat digestion and absorption & 19 & Up & Up/Mixed & Up & Up \\
\hline & & Gastric acid secretion & 27 & $2 \mathrm{D}$ & Up & & \\
\hline & & Mineral absorption & 25 & Up & Up & & \\
\hline & & Protein digestion and absorption & 40 & Up & Up & & \\
\hline & & Vitamin digestion and absorption & 17 & Up & Up & & \\
\hline & Endocrine system & Adipocytokine signaling pathway & 35 & Up/2D & Up/Mixed & & \\
\hline & & Insulin secretion & 37 & $2 \mathrm{D}$ & Up & & \\
\hline & & PPAR signaling pathway & 42 & Up & Up/Mixed & & \\
\hline & Excretory system & $\begin{array}{l}\text { Proximal tubule bicarbonate } \\
\text { reclamation }\end{array}$ & 11 & Up & Up & & \\
\hline & Immune system & B cell receptor signaling pathway & 39 & & & $2 \mathrm{D}$ & Mixed \\
\hline & & Fc epsilon RI signaling pathway & 29 & & & $2 \mathrm{D}$ & Down \\
\hline & & Natural killer cell mediated cytotoxicity & 40 & $2 \mathrm{D}$ & Down & & \\
\hline
\end{tabular}


Table 3 Pathways found to be differentially expressed between control and stress conditions in reciprocal hybrids by both gage and romer packages. The direction of change shown describes the expression of the pathway under stress condition relative to control condition. The terms "2D" and "Mixed" are used to describe pathways in which genes showed bidirectional change. "Genes" refers to the number of genes included in the gene set test

\begin{tabular}{|c|c|c|c|c|c|c|c|}
\hline \multirow[t]{2}{*}{ KEGG group } & \multirow[t]{2}{*}{ KEGG subgroup } & \multirow[t]{2}{*}{ Pathway } & \multirow[t]{2}{*}{ Genes } & \multicolumn{2}{|l|}{ WOPỐ } & \multicolumn{2}{|l|}{ DqWồ } \\
\hline & & & & gage & romer & gage & romer \\
\hline \multirow[t]{3}{*}{ Cellular Processes } & \multirow[t]{3}{*}{ Cell growth and death } & Cell cycle & 88 & Down & Down/Mixed & Down & Down/Mixed \\
\hline & & Cell cycle - yeast & 54 & Down & Down/Mixed & Down & Down/Mixed \\
\hline & & Meiosis - yeast & 41 & Down & Down/Mixed & Down & Down/Mixed \\
\hline \multirow{4}{*}{$\begin{array}{l}\text { Environmental Information } \\
\text { Processing }\end{array}$} & \multirow[t]{3}{*}{ Signal transduction } & ErbB signaling pathway & 40 & & & $2 \mathrm{D}$ & Down \\
\hline & & HIF-1 signaling pathway & 47 & & & Up & Up \\
\hline & & MAPK signaling pathway & 110 & & & $2 \mathrm{D}$ & Up \\
\hline & $\begin{array}{l}\text { Signaling molecules and } \\
\text { interaction }\end{array}$ & $\begin{array}{l}\text { Neuroactive ligand-receptor } \\
\text { interaction }\end{array}$ & 112 & $2 \mathrm{D}$ & Up & Up/2D & Up \\
\hline \multirow[t]{9}{*}{$\begin{array}{l}\text { Genetic Information } \\
\text { Processing }\end{array}$} & $\begin{array}{l}\text { Folding, sorting and } \\
\text { degradation }\end{array}$ & Proteasome & 40 & Down & Down/Mixed & Down & Down/Mixed \\
\hline & \multirow[t]{5}{*}{ Replication and repair } & Base excision repair & 28 & Down & Down/Mixed & Down & Down/Mixed \\
\hline & & DNA replication & 33 & $\begin{array}{l}\text { Down/ } \\
2 \mathrm{D}\end{array}$ & Down/Mixed & Down/2D & Down/Mixed \\
\hline & & Homologous recombination & 20 & Down & Down/Mixed & Down & Down/Mixed \\
\hline & & Mismatch repair & 18 & Down & Down/Mixed & Down/2D & Down/Mixed \\
\hline & & Nucleotide excision repair & 35 & Down & Down/Mixed & Down & Down/Mixed \\
\hline & Transcription & Spliceosome & 109 & Down & Down/Mixed & Down & Down/Mixed \\
\hline & \multirow[t]{2}{*}{ Translation } & $\begin{array}{l}\text { Ribosome biogenesis in } \\
\text { eukaryotes }\end{array}$ & 64 & Down & Down/Mixed & Down & Down/Mixed \\
\hline & & RNA transport & 111 & Down & Down & & \\
\hline \multirow[t]{13}{*}{ Metabolism } & \multirow[t]{4}{*}{ Carbohydrate metabolism } & Citrate cycle (TCA cycle) & 22 & Up & Up & Up & Up \\
\hline & & Galactose metabolism & 16 & Up & Up/Mixed & & \\
\hline & & Glycolysis / Gluconeogenesis & 30 & Up & Up/Mixed & Up & Up/Mixed \\
\hline & & Starch and sucrose metabolism & 21 & & & Up & Up \\
\hline & \multirow[t]{2}{*}{ Energy metabolism } & $\begin{array}{l}\text { Carbon fixation in photosynthetic } \\
\text { organisms }\end{array}$ & 15 & & & Up & Up/Mixed \\
\hline & & Oxidative phosphorylation & 105 & Up & Up & Up & Up \\
\hline & $\begin{array}{l}\text { Glycan biosynthesis and } \\
\text { metabolism }\end{array}$ & $\begin{array}{l}\text { Glycosaminoglycan biosynthesis - } \\
\text { heparan sulfate / heparin }\end{array}$ & 11 & $2 \mathrm{D}$ & Up & & \\
\hline & \multirow[t]{3}{*}{ Lipid metabolism } & Fatty acid degradation & 24 & Up & Up & Up & Up \\
\hline & & Glycerolipid metabolism & 25 & Up & Up & & \\
\hline & & Glycerophospholipid metabolism & 44 & & & Up & Up \\
\hline & $\begin{array}{l}\text { Metabolism of cofactors } \\
\text { and vitamins }\end{array}$ & One carbon pool by folate & 13 & & & Down & Down/Mixed \\
\hline & \multirow[t]{2}{*}{ Nucleotide metabolism } & Purine metabolism & 104 & Down & Down/Mixed & Down & Down/Mixed \\
\hline & & Pyrimidine metabolism & 73 & Down & Down/Mixed & Down & Down/Mixed \\
\hline \multirow[t]{6}{*}{ Organismal Systems } & \multirow[t]{2}{*}{ Circulatory system } & Cardiac muscle contraction & 41 & Up & Up/Mixed & & \\
\hline & & $\begin{array}{l}\text { Vascular smooth muscle } \\
\text { contraction }\end{array}$ & 55 & $2 \mathrm{D}$ & Up & Up/2D & Up \\
\hline & \multirow[t]{4}{*}{ Digestive system } & $\begin{array}{l}\text { Carbohydrate digestion and } \\
\text { absorption }\end{array}$ & 15 & $2 \mathrm{D}$ & Up & & \\
\hline & & Fat digestion and absorption & 19 & Up & Up & Up & Up \\
\hline & & Gastric acid secretion & 27 & & & Up/2D & Up \\
\hline & & Pancreatic secretion & 43 & & & Up & Up \\
\hline
\end{tabular}


Table 3 Pathways found to be differentially expressed between control and stress conditions in reciprocal hybrids by both gage and romer packages. The direction of change shown describes the expression of the pathway under stress condition relative to control condition. The terms "2D" and "Mixed" are used to describe pathways in which genes showed bidirectional change. "Genes" refers to the number of genes included in the gene set test (Continued)

\begin{tabular}{|c|c|c|c|c|c|c|c|}
\hline \multirow[t]{2}{*}{ KEGG group } & \multirow[t]{2}{*}{ KEGG subgroup } & \multirow[t]{2}{*}{ Pathway } & \multirow[t]{2}{*}{ Genes } & \multicolumn{2}{|c|}{ Wo+Dô } & \multicolumn{2}{|l|}{$\mathrm{D}+\mathrm{W} \hat{O}$} \\
\hline & & & & gage & romer & gage & romer \\
\hline & & Protein digestion and absorption & 40 & & & Up & Up \\
\hline & & Vitamin digestion and absorption & 17 & & & Up & Up \\
\hline & Endocrine system & Adipocytokine signaling pathway & 35 & $2 \mathrm{D}$ & Up & Up/2D & Up \\
\hline & & Insulin secretion & 37 & & & Up/2D & Up \\
\hline & & Insulin signaling pathway & 56 & & & Up & Up \\
\hline & & PPAR signaling pathway & 42 & Up & Up/Mixed & Up & Up/Mixed \\
\hline & $\begin{array}{l}\text { Environmental } \\
\text { adaptation }\end{array}$ & Circadian rhythm & 19 & & & $2 \mathrm{D}$ & Up \\
\hline & Immune system & T cell receptor signaling pathway & 61 & & & $2 \mathrm{D}$ & Down \\
\hline & Nervous system & GABAergic synapse & 38 & & & Up & Up \\
\hline & & Glutamatergic synapse & 50 & & & $2 \mathrm{D}$ & Up \\
\hline & & Long-term potentiation & 28 & & & $2 \mathrm{D}$ & Up \\
\hline & & $\begin{array}{l}\text { Retrograde endocannabinoid } \\
\text { signaling }\end{array}$ & 46 & & & $2 \mathrm{D}$ & Up \\
\hline
\end{tabular}

which to investigate the influence that domestication, including directional selection for economically important traits, has on the transcriptome. Evolutionary responses can manifest themselves in changes in gene expression [29]. In this respect, transcriptional differences between wild and domesticated Atlantic salmon strains have been previously recognised and studied in whole animals [30, $31,33]$. Variation in stress responsiveness between genotypes has previously been reported within commercial Atlantic salmon breeding programs [35]. Considering that wild and domesticated fish are adapted to different environments, some aspects of the stress response might be expected to differ. Hatchery rearing alone [36], as well as longer term domestication have been previously shown to reduce stress responsiveness of Atlantic salmon [18].

In the current study, transcriptional divergence between the domesticated strain and wild population in response to stress was supported by multiple lines of evidence. Separation of stress and control, as well as wild, hybrid and domesticated samples was clearly evident from the PCA analysis. Statistical analysis identified a large number of transcripts differentially expressed between wild and domesticated strains, and in response to stress (stress vs control conditions). Moreover, gene set enrichment analyses found numerous functions that were differentially perturbed between the genetic groups tested and/or in response to stress. It should be noted that using RNA from whole individuals prevented tissue specificity of gene expression being investigated, and this needs to be borne in mind when interpreting the potential biological significance of the data. In addition, although organisms respond to stress via coordinated changes of their gene expression, the response can be further modified through various post-transcriptional controls [27, 28]. These changes will not be detected through comparison of mRNA abundances.

\section{Effects of domestication on stress response}

Domestication involves a combination of selection processes. Traits for desired characteristics are methodically selected for, while additional traits may be inadvertently co-selected. Individuals that respond best to the complete package of selection pressures within the domestic environment are those typically chosen as broodstock to propagate the next generation. Using this approach, gains in population-performance are made from generation to generation. Changes in baseline responses to anthropogenic stimuli have been suggested to be an important aspect of domestication [1,2]. Increased stress resilience is one of many traits suggested to differentiate wild and domesticated Atlantic salmon [26]. Although differential stress responsiveness might therefore be expected as a signature of domestication, this was not apparent in the study here, which showed no statistically significant interaction between genetic group and stress response in either analysis $(+/-$ hybrid data). Functional analysis, however, suggested that gene expression in some pathways may reflect a strain-specific stress response. Inclusion of hybrid data in ANOVA analyses of transcript expression for fish under stress / control conditions increased the number of differentially expressed 


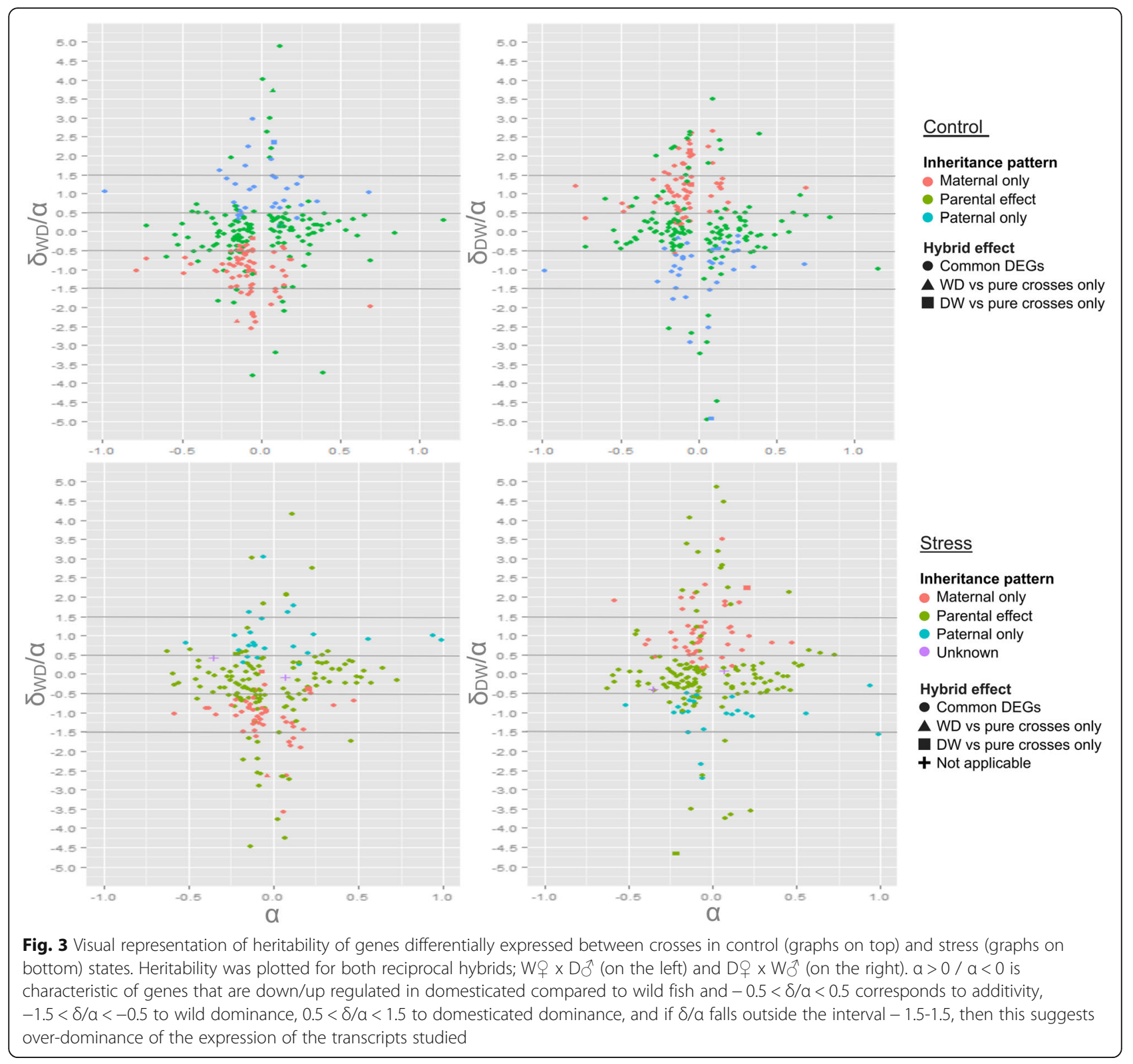

Table 4 Proportions of the differentially expressed genes displaying various inheritance patterns in the reciprocal hybrids relative to the expression of pure crosses under control and stress conditions

\begin{tabular}{|c|c|c|c|c|}
\hline \multirow[t]{2}{*}{ Heritability pattern } & \multicolumn{2}{|l|}{ Control } & \multicolumn{2}{|l|}{ Stress } \\
\hline & $\bar{W}+\times D_{0}$ & $\overline{\mathrm{D}}$ q $\times \mathrm{W} \widehat{0}$ & $\overline{\mathrm{W}}+\mathrm{P} \times \mathrm{D}^{\Uparrow}$ & $\mathrm{D}$ 우 $\times \mathrm{W}^{\wedge}$ \\
\hline Wild overdominant & $10.7 \%$ & $8.9 \%$ & $12.6 \%$ & $7.6 \%$ \\
\hline Wild dominant & $25.8 \%$ & $11.2 \%$ & $31.6 \%$ & $14.8 \%$ \\
\hline Additive & $42.9 \%$ & $40.5 \%$ & $37.9 \%$ & $46.2 \%$ \\
\hline Domesticated dominant & $11.9 \%$ & $23.6 \%$ & $11.2 \%$ & $17.6 \%$ \\
\hline Domesticated overdominant & $8.7 \%$ & $15.8 \%$ & $6.8 \%$ & $13.8 \%$ \\
\hline Number of unique genes & 252 & 259 & 206 & 210 \\
\hline
\end{tabular}




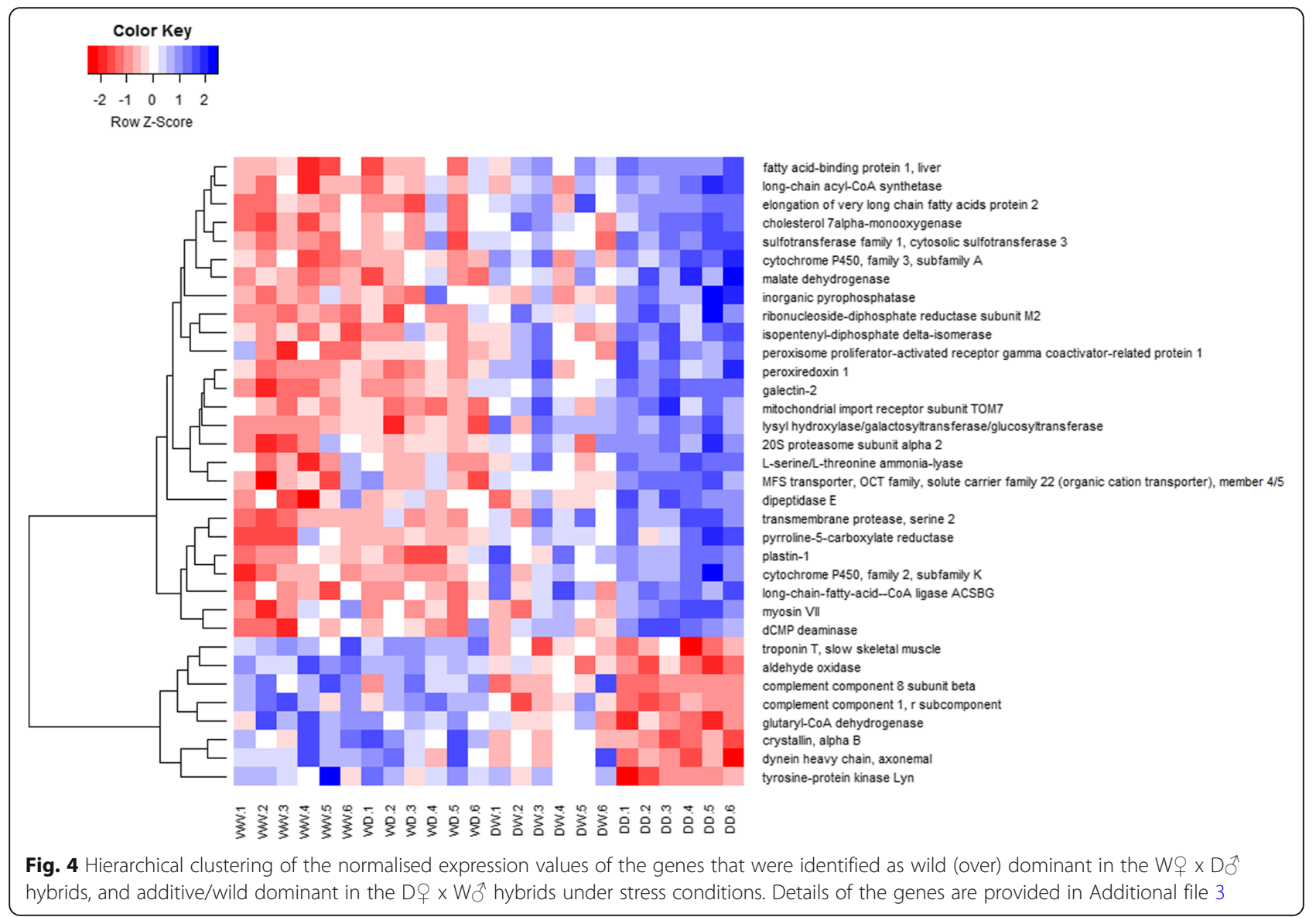

transcripts detected, which could be indicative of heightened responsiveness to stress in hybrids.

\section{Common responses to stress in fish of wild and domesticated origin}

Some cells may respond to stress by reprogramming their metabolism and shifting energy generated by anabolic processes to the repair of stress-induced molecular damage via alteration of the protein translation machinery. In particular, mRNA translation initiation shifts focus from 'housekeeping' to repair processes [28]. Overall, stress is thought to reduce global translation throughout the organism in order to preserve cellular energy [27]. This was reflected in the current study with down-regulation of genetic information processing in response to stress being detected, including pathways of replication and repair, transcription and translation. Cell cycle and meiosis pathways, related to cell growth and death, were similarly affected. In addition, vertebrate stress response involves increased oxygen uptake and transfer, mobilization of energy substrates and reallocation of energy away from growth and reproduction and towards restoration of homeostasis. Increased metabolic rate, as indicated by positive stress-correlated plasma glucose or oxygen consumption, is also associated with the stress response as is immunosuppression [25, 37]. Data from this study indicated that stress increased metabolic processes, including carbohydrate, lipid, and protein metabolism and activities involving co-factors and vitamins. Up-regulation of energy metabolism, circulatory, digestive and endocrine systems and down regulation of immune pathways were also characteristic for all stressed fish.

\section{Strain-specific stress response}

In addition to functional differences shared across the four genetic groups in response to stress, the data also provided evidence of genetic-group-specific stress responses. Indeed, functional differences were found between wild and domesticated pure crosses, as well as between the hybrid strains.

In contrast to the ANOVA analysis, functional analyses of responses to stress identified apparent differences between wild and domesticated origin fish for a number of distinct biological functions. Stress only seemed to affect signaling molecules and interaction pathways, cytokine- 
cytokine and neuroactive ligand-receptor interactions in domesticated fish, whereas changes in metabolic pathways; glycolysis/gluconeogenesis and fatty acid degradation, and the majority of digestive and endocrine system pathways seemed to be characteristic of wild stress response. The expression of all of the unique differences was enhanced in the stressed compared to control fish. Although many of these changes were marginal, being identified by only one or other of the two analytical tools employed (gage or romer), the stress-associated up-regulation of mineral absorption and protein digestion and absorption pathways in wild origin fish cf. domesticated origin fish was fully supported by both packages.

Inclusion of the reciprocal hybrids contributed to an approximately $67 \%$ increase in detection of differentially expressed transcripts responding to stress. In addition, there were more pathways differentially expressed in response to stress in reciprocal hybrids than in pure genetic groups. This suggests that the stress response of the reciprocal hybrids was more substantial and/or more variable, than that of the pure genetic groups. Radical genetic changes, such as alleles entering from one population to another, may disrupt adaptation. In hybrid fish, disruption of adaptation may therefore have engendered a need for more extensive responses to stress in order to maintain homeostatic balance. Enriched pathways observed in both hybrids included signal transduction and nervous system, which were also highlighted in previous studies of fish of wild and domesticated origins [33, 34]. Members of these enriched pathways included MAPK signaling, glutamatergic synapse, long-term potentiation and retrograde endocannabinoid signaling all of which are known to be affected by stress and have been implicated in food intake regulation/growth and/or domestication. MAPK is involved in stress response, growth [38] and domestication [34, 39-42], glutamatergic synapse has been implicated in stress response, feed intake regulation and domestication [24, 34, 43], long-term potentiation has been associated with learning, memory consolidation [44] and domestication [24, 34, 43]. Retrograde endocannabinoid signaling is affected by stress [45] and regulates feeding behaviour [46].

Hybrid type varied in some aspects of their response to stress. Overall, there were more differentially expressed pathways detected in $\mathrm{D} \odot \mathrm{W} \widehat{O}^{\hat{\gamma}}$ hybrids, than in $\mathrm{W} \bigcirc \mathrm{D} \overbrace{}^{\lambda}$ hybrids, primarily affecting functional groups of signal transduction, digestive, endocrine and nervous system pathways. These were mainly up regulated in response to stress. Of these functions, perturbation in protein digestion and absorption, HIF-1 signalling and GABAergic synapse pathways were consistently present in response to stress in $\mathrm{D}$ QW $\widehat{O}$ hybrids but absent in $\mathrm{W} \bigcirc \mathrm{D}{ }^{\lambda}$ hybrids. HIF-1 is a transcription factor that functions as the master regulator of oxygen homeostasis and which is induced in response to reduced oxygen availability and/or by other stimulants, including nitric oxide and various growth factors [47]. GABA is considered as one of the most abundant neurotransmitters in the vertebrate central nervous system, and is involved in a number of neuroendocrine processes including the modulation of feeding and stress response, as well as the stimulation of neural development and differentiation and reproduction [48].

Some of the stress responsive functional differences that differed between the pure and reciprocal hybrid genetic groups were shared. For example, a larger number of digestive and endocrine systems related pathways were perturbed in response to stress in the wild, than in the domesticated group. The same trend, affecting the same pathways, was observed in the $\mathrm{D}+\mathrm{W} \delta$ hybrids compared to $\mathrm{W} \bigcirc \mathrm{D} \widehat{\wedge}$ hybrids. Although largely the result of either gage or romer failing to detect some of these pathways, it indicates that for digestive and endocrine functions, wild pure and $\mathrm{D}+\mathrm{W} \delta$ hybrids had a more consistent and/or stronger stress response, than pure

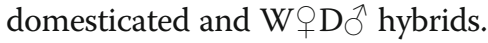

\section{Biological functions down-regulated in fish of domesticated origin}

Cellular signalling functions in homeostasis by controlling cell replication, differentiation and apoptosis and helps to regulate metabolic events. Stimuli for responses include nutritional state, inflammatory signals or alteration of the organism's physical environment, these being factors likely to differ between natural and artificial niches. Down-regulation of signalling pathways in domesticated fish may be indicative of these animals being better adapted to the more consistent farm environment such that they require less sensitivity or capacity to maintain homeostasis.

Reduction of information acquisition and processing systems, including those involving sensory organs and synapses with transmitter substances for information processing, has been proposed to be a consequence of domestication [23]. The current study supports this hypothesis, with both cell communication and nervous system pathways being found to be down-regulated in fish of domesticated origin compared to wild. Further support comes from previous studies, where for the same stocks, cell communication pathways gap junction and focal adhesion were observed to be differentially expressed between wild and domesticated origin embryos [34] and nervous system related pathways synaptic vesicle cycle and serotonergic synapse were down regulated in the domesticated origin sac fry [33]. Glutamatergic synapse was also identified as differentially perturbed/down regulated in domesticated embryo/sac fry respectively $[33,34]$. Generally, decreased 
serotonergic activity is associated with dominance, boldness and aggression [49]; behaviours more prominent in domesticated fish when compared to wild counterparts in the hatchery environment [50]. Glutamate is a major excitatory neurotransmitter that regulates various behaviours and emotions and is involved in learning and memory [51]. Changes in glutamate metabolism are suggested to have occurred during domestication of dogs [24] and pigs (Sus scrofa domesticus) [43]. Expression of glutamate receptors seems to affect the neural control of eating behaviours in pigs [43], with their deficiency having been shown to decrease fear and anxiety in mammals and their up regulation having been hypothesised to enhance excitatory synaptic plasticity in dogs [24]. Up regulation of glutamate activity and hence increased fear and anxiety in dogs compared to wolves is contrary to what one might expect in response to domestication. However, the authors argued that its beneficial effects in terms of strengthening the dogs' learning and memory abilities outweighed the effects of fearfulness since it aids the accurate interpretation of human behaviour.

Another major down-regulated functional group detected in domesticated fish in the current study, and also in domesticated embryos [34] and in sac and feeding fry [33] belonging to the same strains, was immune system. In fish, the neuroendocrine and immune systems are interlinked through shared cytokines and neuropeptides $[52,53]$ and most of the differentially expressed immune pathways identified in the current study were involved in signalling. Since the importance that particular traits have in the wild, shifts during selection for domestication, the energy invested in them similarly has to be optimised to the new environment. In part this must be achieved through the (re) allocation of resources, and such a trade-off has been identified between growth and immune function, especially in livestock selected for increased production traits [22]. In line with the resource allocation theory, data from the current study showed down-regulation of immune pathways in domesticated fish and simultaneous up-regulation of metabolism, endocrine and digestive systems and genetic information processing. This is consistent with previous studies that have demonstrated significantly increased growth rates in farmed salmon in comparison with their wild counterparts under identical conditions [17-21, 54].

\section{Biological functions up-regulated in fish of domesticated origin}

Greater consumption and more efficient utilization of fish feed for growth was reported for Atlantic salmon selected for increased growth over five generations compared to wild counterparts [55]. In addition, selection for growth was suggested to be likely to result in individuals with more active endocrine systems [56]. Such differences were evident from the results of the current study, with up-regulation of metabolism and in particular of carbohydrate and lipid metabolism and digestive and endocrine system pathways in the domesticated compared to wild fish. In addition, cellular processes, such as cell cycle and peroxisome and genetic information processing, including DNA replication, $m R N A$ transcription and translation, indicative of protein production and growth, were also more highly represented in fish of domesticated origin than in wild origin counterparts.

Functional groupings and regulation of the differentially expressed transcripts detected between fish of domesticated and wild origins were largely consistent between control and stress conditions, as shown by the biological pathways identified and their direction of change. Overall, fewer pathways were identified as differentially expressed in the stress state. This could be a result of individual differences in stress response that may have introduced greater variability in the data and thereby reduced the ability to detect consistent differences in transcript expression. However, the adoption of a pooled design in the current study should decrease the effects of individual variation. Differences were observed in digestive system; including protein and vitamin digestion and absorption and mineral absorption pathways. As these pathways were up-regulated in domesticated compared to fish of wild origin and were up-regulated in response to stress only in the wild fish, it is likely that under stress conditions the increased wild expression masked the difference between wild and domesticated fish of these pathways, resulting in a lack of detectable significant difference..

\section{Heritability of transcriptomic differences}

Most transcriptomic differences detected between the four genetic groups were additive, with c. $40 \%$ of differentially expressed transcripts exhibiting intermediate expression in hybrids compared to the pure crosses. Additive genetic variation has been suggested to be characteristic of important Atlantic salmon traits, such as survival $[12,13,57]$, growth [17-21, 58], and phenology [13]. Moreover, additive inheritance of gene expression is widespread between conspecifics from widely divergent salmonid populations, including wild and domesticated Atlantic salmon [32-34], brook charr [59] and dwarf and normal lake white fish [60].

Parental effects were differentiated from the effects of domestication by investigating the heritability patterns of the reciprocal hybrids. The majority of the genes showing dominance $(18-32 \%)$ followed the behaviour of the dam in hybrids and therefore it is clear that that dominance was largely a maternal property, irrespective of genetic origin. Fewer genes displayed paternal dominance behaviour (11-15\%), an observation also reported 
for wild and domesticated brook charr, where $40 \%$ of the differentially expressed genes exhibited maternal and 5\% paternal dominance [59]. Maternal effects are common in salmonids and have been associated with egg and nest quality [61], and egg and alevin size and survival [12, 62-65]. Maternal effects are likely to be influenced by both genetic and environmental sources of variation [66]. The influence of these components on the phenotype are subject to change over time, and a shift from larger maternal environmental effects to larger genetic effects has been shown during the development of Atlantic salmon [67]. Maternal influence tends to decline over time, including that due to transcriptomic differences [68]. This trend was evident for the extent of maternal over-dominance, for the same strains studied here. The number of transcripts governed by overdominance steadily decreased from approximately $20 \%$ in the embryo stage [34], through a mean of 13 to $5 \%$ in fry approximately 3 weeks (Table 4) and 5 weeks [33] post first feeding respectively.

The contribution from additivity and maternal dominance, was consistent between reciprocal hybrids of the control state, but less so in the stress state. This was due to the relatively large proportion of genes that were wild dominant in the $\mathrm{W} O \times \mathrm{D} \widehat{\gamma}$ hybrids, and were additive/ wild dominant in $\mathrm{D} q \mathrm{x}$ W $\sigma^{-}$hybrids under stress. This suggests that these genes were under wild dominance, as opposed to maternal dominance regardless of the maternal status. Maternal effects can be adaptive or maladaptive depending on whether the maternal environment is reflective of the offspring's environment. There are a range of factors known to influence environmental maternal effects including maternal diet and stress experiences [61] that likely vary between natural and farm conditions. Since many of the genes indicative of maternal environmental effects are stress responsive and are involved in lipid and energy metabolism, their expression pattern could be affected by differences in the way wild and domesticated fish metabolise feed, experience stress and produce energy in response to it. In the current study, the expression of the affected genes was more consistent in domesticated origin fish than it was in wild origin fish under stress conditions. This may reflect greater variability of expression of these genes in response to stress in the wild population. Reduced genetic variation has been previously reported for fitness related QTLs in response to domestication, possibly due to genetic sweeps [69].

\section{Conclusions}

This study investigated the functional significance and heritability of transcriptomic differences between Atlantic salmon fry of wild and domesticated origin, maintained under standard hatchery and acute stress conditions. Differences observed were discussed in terms of the contrasting selection pressures acting on natural and aquaculture populations. Although a higher number of responsive pathways were detected in wild origin fish in response to stress, many of the affected pathways were common to fish of both wild and domesticated origin. The major stress-responsive functional groups were indicative of mobilisation and re-allocation of energy. Reciprocal hybrids exhibited similar transcriptomic stress responses to pure domesticated and wild origin stocks, however, some functions that were detected to be differentially expressed between wild and domesticated fish were also found between stress and control hybrids. Additivity and maternal dominance were observed to be the most important modes of inheritance for differential transcript expression detected between the stocks.

\section{Methods \\ Biological samples}

The domesticated broodstock used in this study originated from the Norwegian Mowi strain. This commercial strain has been maintained in culture for $>10$ generations and has been selected for a range of commercially important traits, for example fast growth, reduced early maturation, improved flesh characteristics and disease resistance. In experimental comparison with wild and F1 hybrid populations, this domesticated strain has been previously demonstrated to display several-fold higher growth rates under hatchery conditions [17-20, $70]$, and lower survival in the wild [12, 13, 69]. Wild adult broodstock originated from the Figgjo River in southwest Norway. Scale samples from these fish were taken to confirm their wild origin [71]. For further details regarding the genetic background of the strains used in this study, the reader is referred elsewhere [18, 33].

After simultaneously stripping the domesticated and wild broodstock, experimental families (wild, two groups of reciprocal hybrids, domesticated) were established on 23rd November 2011 at the Institute of Marine Research's experimental fish farm in Matre, Norway. These families are here on referred to as the four genetic groups, and

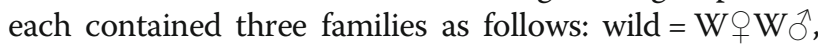

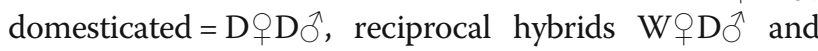
$\mathrm{D}+\mathrm{W}{ }^{\lambda}$. All of the families within each genetic group were full-siblings to each other (i.e., had 6 unique parents), but the reciprocal hybrids were half-siblings compared to their paternal and maternal pure strains. This required a total of 12 broodstock to generate the 12 families distributed among the 4 genetic groups.

Adipose fin samples from the parents and caudal fin samples from the offspring were retained for DNA profiling. Fertilised eggs were reared under standard 


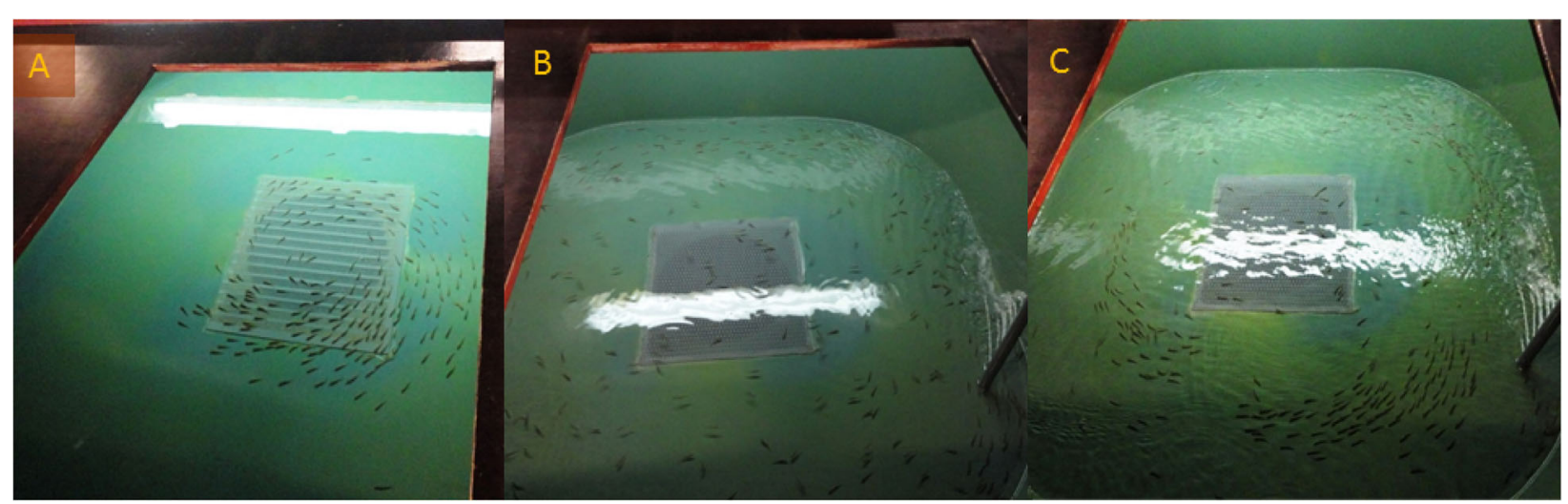

Fig. 5 Behaviour patterns of the fish during the experiment. a. Prior to stress, fish exhibited schooling behaviour and responded to human presence. $\mathbf{b}$. Following the reduction of the water depth, fish broke schooling structure, were distributed randomly in the tanks and did not respond to human presence. c. After spending approximately 20 min in shallow water, more structured swimming was observed and fish became responsive to human presence

hatchery conditions in single family incubators at ambient temperature $\left(4.2-8.1^{\circ} \mathrm{C}\right)$. At the eyed egg stage on 2nd February 2012, all 12 families ( 3 families $\times 4$ genetic groups) were mixed to generate four replicates, each comprising 30 individuals per family (i.e. 4 replicates each with 360 eggs). These four experimental replicates where thereafter reared in four compartments within the same tank. On 28th March 2012 hatched fry from each of the four replicates were transferred into four separate tanks containing heated water $\left(\mathrm{n}\right.$ tanks $=4,13^{\circ} \mathrm{C}, 1 \mathrm{~m}^{3}$, $45 \mathrm{~cm}$ water depth) immediately prior to initiation of exogenous feeding. Thereafter, fry were fed on standard hatchery diet $24 \mathrm{~h}$ a day by automatic feeders.

A stress challenge (including controls) was started on 17th April 2012 (3 weeks post initiation of first feeding, and $985^{\circ} \mathrm{d}$ post-fertilization). During the stress challenge feeding in all four tanks was stopped. Water level in two of the replicate tanks (the stress replicates) was altered over a $24 \mathrm{~h}$ period; $3 \mathrm{~h}$ at low depth $(2.5 \mathrm{~cm})$ followed by $3 \mathrm{~h}$ at normal depth $(45 \mathrm{~cm})$. This procedure was repeated 4 times during the $24 \mathrm{~h}$ period. In addition to crowding, at low water level, the fish experienced increased water splashing from the inlet feed and increased current velocities. As a first response fish broke schooling structure and were distributed randomly in the tanks (Fig. 5). After approximately $20 \mathrm{~min}$ more structured swimming was observed and fish became responsive to human presence, which was not the case in the initial phase (Fig. 5). Water levels in the remaining two 'control' tanks were not manipulated. After $24 \mathrm{~h}$, fish from all four tanks were euthanized with metacaine (Finquel ${ }^{\circ}$ Vet, Scanvacc, Årnes, Norway), and transferred immediately into an RNA stabilisation buffer (3.6 M ammonium sulphate, $18 \mathrm{mM}$ Sodium Citrate, $15 \mathrm{mM}$ EDTA, pH 5.2). After $24 \mathrm{~h}$ incubation at $10^{\circ} \mathrm{C}$ in this buffer the fry were removed and stored at $-70^{\circ} \mathrm{C}$ until molecular analysis.

\section{Family assignment}

To assign individual fish sampled from all of the four experimental tanks to their families, and thus genetic group of origin, microsatellite genotyping was performed at the Institute of Marine Research's molecular genetics laboratory in Bergen, Norway. This laboratory has extensive experience in parentage testing in Atlantic salmon $[18,19,21]$, and uses the microsatellite markers implemented here for forensic investigations [72, 73]. A total of 846 fry were genotyped to randomly identify a minimum of 24 individuals from each family and from both conditions (control and stress). As there were two replicates per treatment, this meant that 12 individuals were sampled per family and per control or stress tank. DNA was extracted from tail samples in 96 well plate format using a Qiagen DNeasyW96 Blood \& Tissue Kit following manufacturer's instructions. Five microsatellite loci were amplified in one multiplex PCR; SsaF43 [GenBank: U37494], Ssa197 [GenBank: U43694.1], SSsp3016 [GenBank: AY372820], MHCI [74] and MHCII [75], PCR products were run on an ABI 3730 Genetic Analyser and size-called according to the $500 \mathrm{LIZ}^{\mathrm{in}}$ standard. Genotypes were identified using GeneMapper V4.0 (Applied Biosystems, Thermo Fisher Scientific, Waltham, Massachusetts, USA) and family assignment was performed via FAP; Family Assignment Program v3.6 [76]. Individuals unambiguously assigned to families were used in the transcriptomic analysis.

\section{Microarray experimental design}

Although three families per genetic group were included in the stress experiment, scale reading [71] after familyproduction suggested that one of the wild broodstock used was a farmed escapee. Consequently, in order to not influence the results of the present study, microarray analysis was restricted to include only the two families 


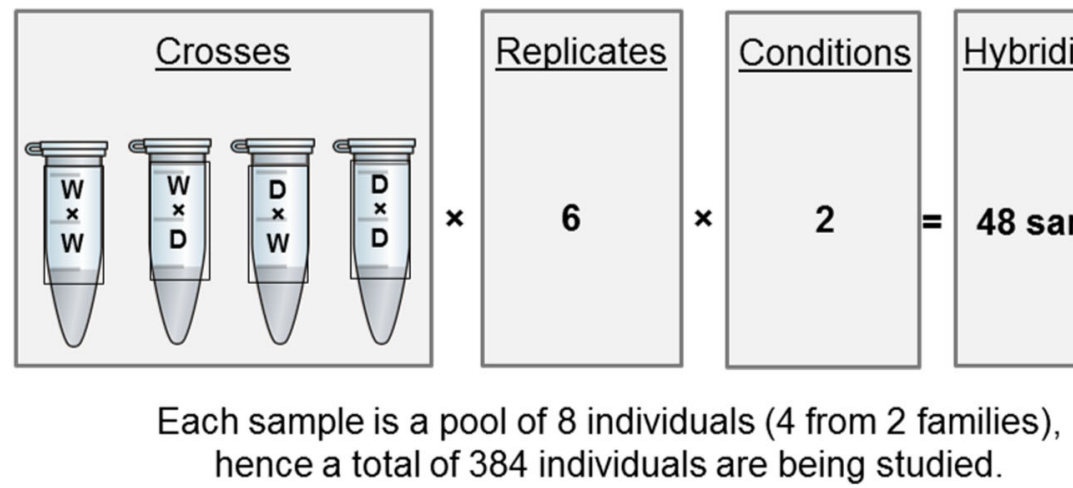

Fig. 6 A schematic representation of the experimental design

per genetic group where their origin was identified with confidence.

Microarray analysis was performed using a customdesigned, oligonucleotide microarray platform (Agilent) with four $44 \mathrm{~K}$ probe arrays per slide (Salar_3; ArrayExpress accession number A-MEXP-2400). The general design of the microarray has been described in detail elsewhere [77] and further used and validated in a number of subsequent studies [33, 34, 78, 79].

Dual-label hybridisations were undertaken, with each experimental sample (Cy3 labelled) being competitively hybridised against a pooled reference control (Cy5 labelled) comprising equimolar amounts from each experimental RNA sample. The interrogations comprised 48 separate hybridisations (Fig. 6): 4 genetic groups (wild, domesticated and $2 \mathrm{x}$ reciprocal hybrids), 2 conditions (stress and control) and 6 biological replicates (2 tank replicates; 3 pooled samples per tank, each pooled sample comprising 4 individuals from each of 2 families).

\section{RNA extraction and purification}

Whole fry $(n=384)$ were rapidly homogenised in Tri Reagent (Sigma-Aldrich ${ }^{\odot}$, St. Louis, U.S.A.) using a Mini-Beadbeater-24 (BioSpec Products Inc., Bartlesville, USA) and RNA extracted following the manufacturer's instructions. RNA quantity and quality were assessed by spectrophotometry (NanoDrop ND-1000, Thermo Scientific, Wilmington, U.S.A.) and agarose gel electrophoresis respectively. For each biological replicate (hybridisation sample), equal amounts of total RNA from eight individuals per tank were pooled (four fry per family, two families per genetic group) and then requantified and quality assessed as described above.

\section{RNA amplification and labelling}

Each pooled RNA sample was amplified (TargetAmp 1Round Aminoallyl-aRNA Amplification Kit, Epicentre Technologies Corporation, Madison, Wisconsin, USA) according to the manufacturer's instructions. Following quality control (Nanodrop quantification and agarose gel electrophoresis) each aRNA sample was indirectly labelled and purified. Briefly, Cy dye suspensions (Cy3 and Cy5) in sufficient quantity for all labelling reactions were prepared by adding $42 \mu \mathrm{L}$ high purity dimethyl sulphoxide (Stratagene, Hogehilweg, The Netherlands) per tube of Cy dye (PA23001 or PA25001; GE HealthCare, Little Chalfont, Bucks, UK). Individual samples $\left(2.5 \mu \mathrm{g}\right.$ aRNA in $\left.10.5 \mu \mathrm{L} \mathrm{H} \mathrm{H}_{2} \mathrm{O}\right)$ were denatured at $75^{\circ} \mathrm{C}$ for $5 \mathrm{~min}$ and then $3 \mu \mathrm{L} 0.5 \mathrm{M} \mathrm{NaHCO} \mathrm{pH}_{3} .5$ and $1.5 \mu \mathrm{L}$ Cy3 dye added. The reference pool consisted of the same proportions per sample, but $1 \mu \mathrm{L}$ Cy 5 dye was used to label $2.5 \mu \mathrm{g}$ pooled aRNA. Samples were incubated for an hour at $25^{\circ} \mathrm{C}$ in the dark, purified using an Illustra AutoSeq G-50 Dye Terminator Removal Kit (Qiagen GE Healthcare), and concentration, dye incorporation and purity were assessed via spectrophotometer (NanoDrop) with products also visualised on a fluorescent scanner (Typhoon Trio, GE Healthcare).

\section{Microarray hybridisation and quality filtering}

Hybridisation was performed over two consecutive days (24 arrays per day) using the Agilent Gene Expression Hybridisation Kit (Agilent Technologies) as per manufacturer's instructions. For each reaction, $825 \mathrm{ng}$ Cy5 labelled reference pool and $825 \mathrm{ng}$ Cy3 labelled individual samples were combined in $35 \mu \mathrm{L}$ nuclease free water and then $20 \mu \mathrm{L}$ fragmentation master mix added $(11 \mu \mathrm{L}$ of 10x blocking agent, $2 \mu \mathrm{L} 25 \mathrm{x}$ fragmentation buffer and $7 \mu \mathrm{L}$ nuclease free water). The reactions were then incubated at $60^{\circ} \mathrm{C}$ in the dark for 30 mins, chilled on ice, and mixed with $57 \mu \mathrm{L} 2 \mathrm{x}$ GEx Hybridisation buffer (pre heated to $37^{\circ} \mathrm{C}$ ), Following centrifugation $(18,000 \mathrm{x} \mathrm{g}$ for $1 \mathrm{~min}$ ) the samples were kept on ice until loaded $(103 \mu \mathrm{L})$ in a structured randomised order onto the microarray slides. Samples from the six biological replicates were divided across different slides, Cy3 
fluorescence content (dye incorporation rate $\mathrm{x}$ volume) was also taken into consideration. To aid scanning, samples with the most similar amounts of $\mathrm{Cy} 3$ were grouped on the same slide. Hybridisation was carried out in a rotating rack oven (Agilent Technologies) at $65^{\circ} \mathrm{C}, 10 \mathrm{rpm}$ over $17 \mathrm{~h}$.

Following hybridisation, slides were washed in EasyDipTM slide staining containers (Canemco Inc., Quebec, Canada). First, a $1 \mathrm{~min}$ incubation at room temperature (c. $20^{\circ} \mathrm{C}$ ) in Wash Buffer 1 was performed, with gentle shaking at $150 \mathrm{rpm}$ (Stuart Orbital Incubator). Slides were briefly dipped into Wash Buffer 1 pre-heated to $31^{\circ} \mathrm{C}$, then placed into Wash Buffer $2\left(31^{\circ} \mathrm{C}\right)$ for $1 \mathrm{~min}$ at $150 \mathrm{rpm}$. Finally, the slides were transferred to acetonitrile for 10s and then Agilent Stabilization and Drying Solution for $30 \mathrm{~s}$. The slides were then air dried in the dark and scanned within $3 \mathrm{~h}$.

Scanning was carried out at $5 \mu \mathrm{m}$ resolution on an Axon GenePix Pro scanner at $70 \%$ laser power. The "auto PMT" function was enabled to adjust PMT for each channel such that less than $0.1 \%$ of features were saturated and so that the mean intensity ratio of $\mathrm{Cy} 3$ : Cy5 signal was close to one. Agilent Feature Extraction Software (v 9.5) was used to identify features and extract background subtracted raw intensity values that were then transferred to GeneSpring GX (version 13.0) software where the quality filtering and normalisation steps took place. Intensity values $\leq 1$ were adjusted to 1 and a Lowess normalisation undertaken. Stringent quality filtering ensured that features that represented technical controls, saturated probes, probe population outliers or probes which were not significantly different from the background were removed. Agilent feature extraction software was used to determine whether a probe was positive and significant based on a 2-sided t-test, indicating whether the mean signal of a feature was greater than the corresponding background. A probe was retained if it was positive and significant in at least $75 \%$ of the arrays in any 4 of the 8 experimental groups. This process resulted in 30,164 of the original 43,413 probes being considered eligible for downstream analysis.

\section{Microarray data analysis}

Three dimensional principal component analysis (3DPCA) was performed on normalised data in GeneSpring on all transcripts that passed quality filtering. The PCA algorithm also applies a further normalisation step to 'mean-centre (zero mean) the data. The covariance analysis was computed on the overall gene expression of individual samples. I.e., on all probes that have passed quality filtering. The number of principal components was set to four (default) with the three principal components that explained the major trends of variation shown on the axes. This PCA is solely based on gene expression and independent of experimental grouping.
To investigate genetic group-specific stress response, differentially expressed transcripts were identified in GeneSpring using a 2-way ANOVA. Here, genetic group (wild, reciprocal hybrids, domesticated) and condition (stress and control) were considered as factors and multiple testing correction (Benjamini-Hochberg, $p<0.05$ ) was performed. The above statistical analysis was carried out on all four genetic groups, and in addition, on the two pure genetic groups (i.e., wild and domesticated only).

KEGG-based functional analyses of genetic group and condition-specific transcriptomic differences were explored via two analytical approaches, both carried out in $R$ software v.3.1.3 [80]. First, rank-based GAGE analysis (Generally Applicable Gene-set/Pathway Analysis) [81] was performed, implementing Mann Whitney U tests, then the romer function from the limma package (Linear Models for Microarray Data) [82] was used to achieve more robust results, that are supported by different methods. For GAGE results, the software-recommended default FDR "q-value" cut-off $<0.1$ was applied. For both techniques, a total of six contrasts were considered. First, to address the primary aim of the experiment, identifying functional differences related to domestication, the domesticated and wild genetic groups were compared under control (genetic group control) and stress (genetic group stress) conditions separately. Then, to identify responses of each genetic group to the stress treatment, stressed fish of wild and domesticated origin were compared to control fish from the corresponding genetic groups (Condition wild and Condition domesticated). Finally, the effect of stress was also investigated for the hybrid groups (Condition WD and Condition DW). To achieve unique KO-probe associations, where multiple probes were assigned to the same $\mathrm{KO}$ number, probes with the lowest overall $p$-value based on a 2-way ANOVA were chosen. Since pathways belonging to the human disease functional group are particularly problematic to interpret in fish, this group was excluded from the gene enrichment analysis. The significant pathways jointly supported by both analyses are discussed. The complete lists of pathways identified by the gage and romer functions are supplied in Additional files 1 and 2 respectively.

To look at heritability of differentially expressed genes between the four genetic groups, 1-way ANOVA (unequal variance) was performed with 5\% FDR (BenjaminiHochberg) and Student Newman-Keuls (SNK) post-hoc analysis using GeneSpring. To avoid repeated counting of the same gene, only transcripts that had KEGG annotation available were selected and where multiple probes were present for the same gene, the probe with the highest significance was chosen. The obtained genes were assigned to the following heritability categories: 
Maternal effect: differential expression between

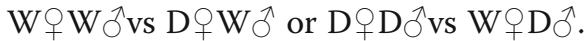

Paternal effect: differential expression between

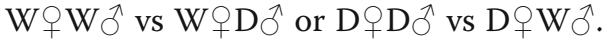

Parental effect: influenced by both maternal and paternal effects.

Maternal only: unique to maternal effect.

Paternal only: unique to paternal effect.

Additivity $(\alpha)$ and dominance $(\delta)$ values were calculated from normalised intensity values (ni) for unique differentially expressed genes, where $\alpha=\left(\mathrm{W}_{n \mathrm{ni}}-\mathrm{D}_{\mathrm{ni}}\right) / 2$ and $\delta=\left(\left(\mathrm{W}_{\mathrm{ni}}+\mathrm{D}_{\mathrm{ni}}\right) / 2\right)-$ hybrid $_{\mathrm{ni}}$. For visualisation $\alpha$ was plotted against $\delta / \alpha$ (Fig. 3) using the ggplot2 package [83]. By definition, a transcript whose expression value in hybrids is midway between that of the parents is additive (perfect additivity: $\delta / \alpha=0$ ), whereas a transcript whose hybrid gene expression value resembles one of the two parents more closely is dominant (domesticated dominance, $\delta / \alpha=1$; wild dominance, $\delta / \alpha=-1$ ). By halving the intervals, transcripts were assigned to modes of heritability, as follows:

- additivity if $-0.5<\delta / \alpha<0.5$.

- wild dominance if $-1.5<\delta / \alpha<-0.5$.

- domesticated dominance if $0.5<\delta / \alpha<1.5$.

- over-dominance if $\delta / \alpha$ falls out of the interval - 1.5-1.5.

For ease of plot interpretation, genes with $|\delta / \alpha|>5$ were excluded from the scatter graph but were considered in the heritability table.

Finally, when appropriate, selected annotated (KEGG) gene lists were subjected to hierarchical clustering (Pearson correlation) using the heatmap. 2 function of the gplots $R$ package and presented as a heatmap.

\section{Supplementary information}

Supplementary information accompanies this paper at https://doi.org/10. 1186/s12863-020-00858-y.

Additional file 1. The complete lists of KEGG pathways identified by the gage function

Additional file 2. The complete lists of KEGG pathways identified by the romer function.

Additional file 3. Details of the genes that formed the basis of Fig. 6 .

\section{Acknowledgements}

The authors wish to thank Lise Dyrhovden and Ivar Helge Matre for their assistance in producing and Anne-Grete Sørvik for genotyping the fish upon which the current study is based.

\section{Authors' contributions}

BB performed the experimental sampling, carried out the laboratory work, data analysis and drafted the manuscript. KAG organized the production and maintenance of the crosses during the experiment. BB, KAG, JBT and JEB contributed to the experimental design and analysis and were involved in authoring the manuscript. The author(s) read and approved the final manuscript.

\section{Funding}

This study was financed by the Norwegian Research Council, project number 200510 INTERACT. The authors also acknowledge the support of the Marine Alliance for Science and Technology Scotland (MASTS) pooling initiative, funded by the Scottish Funding Council (grant reference HR09011). The funding bodies played no part in the design of the study, interpretation of data not presentation.

\section{Availability of data and materials}

Details of the microarray experiment have been submitted to ArrayExpress (www.ebi.ac.uk/arrayexpress) under accession number E-MTAB-3679 and are therefore openly available. The recording of the microarray experimental metadata complies with Minimum Information About a Microarray Experiment (MIAME) guidelines.

\section{Ethics approval and consent to participate}

The experiment was conducted in accordance with Norwegian regulations for the use of animals in research. The experimental protocol was approved by the Norwegian Animal Research Authority (NARA) (Norwegian research permit 4368).

\section{Consent for publication}

Not applicable.

\section{Competing interests}

The authors declare that they have no competing interests.

\section{Author details}

'Institute of Aquaculture, School of Natural Sciences, University of Stirling, Stirling FK9 4LA, UK. ${ }^{2}$ Institute of Marine Research, Bergen, Norway.

${ }^{3}$ Department of Biology, University of Bergen, Bergen, Norway.

Received: 28 October 2019 Accepted: 12 May 2020

Published online: 29 May 2020

References

1. Price EO. Behavioral aspects of animal domestication. Q Rev Biol. 1984;59(1): $1-32$.

2. Price EO. Behavioral development in animals undergoing domestication Appl Anim Behav Sci. 1999:65(3):245-71.

3. Gjedrem T. Genetic improvement of cold-water fish species. Aquac Res. 2000;31(1):25-33.

4. Gjedrem T. The first family-based breeding program in aquaculture. Rev Aquac. 2010;2(1):2-15.

5. Teletchea F, Fontaine P. Levels of domestication in fish: implications for the sustainable future of aquaculture. Fish Fish. 2014;15(2):181-95.

6. Johnsson JI, Hojesjo J, Fleming IA. Behavioural and heart rate responses to predation risk in wild and domesticated Atlantic salmon. Can J Fish Aquat Sci. 2001;58(4):788-94.

7. Einum S, Fleming IA. Genetic divergence and interactions in the wild among native, farmed and hybrid Atlantic salmon. J Fish Biol. 1997;50(3): 634-51.

8. Houde ALS, Fraser DJ, Hutchings JA. Reduced anti-predator responses in multi-generational hybrids of farmed and wild Atlantic salmon (Salmo salar L.). Conserv Genet. 2010;11(3):785-94.

9. Solberg MF, Robertsen G, Sundt-Hansen LE, Hindar K, Glover KA. Domestication leads to increased predation susceptibility. Sci Rep. 2020 10(1):1929.

10. McGinnity P, Prodohl P, Ferguson K, Hynes R, O'Maoileidigh N, Baker N, Cotter D, O'Hea B, Cooke D, Rogan G, et al. Fitness reduction and potential extinction of wild populations of Atlantic salmon, Salmo salar, as a result of interactions with escaped farm salmon. Proc R Soc Lond Ser B-Biol Sci. 2003; 270(1532):2443-50

11. Fleming IA, Hindar K, Mjolnerod IB, Jonsson B, Balstad T, Lamberg A. Lifetime success and interactions of farm salmon invading a native population. Proc R Soc Lond Ser B-Biol Sci. 2000;267(1452):1517-23.

12. Skaala $\varnothing$, Glover KA, Barlaup BT, Svåsand T, Besnier F, Hansen MM Borgstrøm R. Performance of farmed, hybrid, and wild Atlantic salmon (Salmo salar) families in a natural river environment. Can J Fish Aquat Sci. 2012;69(12):1994-2006. 
13. Skaala O, Besnier F, Borgstrom R, Barlaup B, Sorvik AG, Normann E, Ostebo $\mathrm{BI}$, Hansen MM, Glover KA. An extensive common-garden study with domesticated and wild Atlantic salmon in the wild reveals impact on smolt production and shifts in fitness traits. Evol Appl. 2019;12(5):1001-16.

14. Glover KA, Pertoldi C, Besnier F, Wennevik V, Kent M, Skaala Ø. Atlantic salmon populations invaded by farmed escapees: quantifying genetic introgression with a Bayesian approach and SNPs. BMC Genet. 2013;14:4.

15. Clifford SL, McGinnity P, Ferguson A. Genetic changes in Atlantic salmon (Salmo salar) populations of northwest Irish rivers resulting from escapes of adult farm salmon. Can J Fish Aquat Sci. 1998;55(2):358-63.

16. Wringe BF, Jeffery NW, Stanley RRE, Hamilton LC, Anderson EC, Fleming IA, Grant C, Dempson JB, Veinott G, Duffy SJ, et al. Extensive hybridization following a large escape of domesticated Atlantic salmon in the Northwest Atlantic. Commun Biol. 2018;1:9.

17. Glover KA, Ottera H, Olsen RE, Slinde E, Taranger GL, Skaala O. A comparison of farmed, wild and hybrid Atlantic salmon (Salmo salar L.) reared under farming conditions. Aquaculture. 2009;286(3-4):203-10.

18. Solberg MF, Glover KA, Nilsen F, Skaala $\varnothing$. Does domestication cause changes in growth reaction norms? A study of farmed, wild and hybrid Atlantic salmon families exposed to environmental stress. PLoS One. 2013; 8(1):e54469.

19. Solberg MF, Zhang ZW, Nilsen F, Glover KA. Growth reaction norms of domesticated, wild and hybrid Atlantic salmon families in response to differing social and physical environments. BMC Evol Biol. 2013;13:234.

20. Harvey A, Glover KA, Taylor MI, Creer S, Carvalho GR. A common garden design reveals population-specific variability in potential impacts of hybridization between populations of farmed and wild Atlantic salmon, Salmo salar L. Evol Appl. 2016:9:435-49.

21. Harvey AC, Skilbrei OT, Besnier F, Solberg MF, Sorvik AGE, Glover KA. Implications for introgression: has selection for fast growth altered the size threshold for precocious male maturation in domesticated Atlantic salmon? BMC Evol Biol. 2018;18:13.

22. Rauw WM. Immune response from a resource allocation perspective. Front Genet. 2012:3:267.

23. Hemmer $\mathrm{H}$. Domestication: the decline of Environmental appreciation Cambridge: Cambridge University Press; 1990.

24. Li Y, Wang GD, Wang MS, Irwin DM, Wu DD, Zhang YP. Domestication of the dog from the Wolf was promoted by enhanced excitatory synaptic plasticity: a hypothesis. Genome Biol Evol. 2014;6(11):3115-21.

25. Bonga SEW. The stress response in fish. Physiol Rev. 1997;77(3):591-625.

26. Glover KA, Solberg MF, McGinnity P, Hindar K, Verspoor E, Coulson MW, Hansen MM, Araki H, Skaala $\varnothing$, Svåsand T. Half a century of genetic interaction between farmed and wild Atlantic salmon: status of knowledge and unanswered questions. Fish Fish. 2017;18(5):890-927.

27. Holcik M, Sonenberg N. Translational control in stress and apoptosis. Nat Rev Mol Cell Biol. 2005;6(4):318-27.

28. Yamasaki S, Anderson P. Reprogramming mRNA translation during stress. Curr Opin Cell Biol. 2008;20(2):222-6.

29. Carroll SB. Evolution at two levels: on genes and form. PLoS Biol. 2005;3(7): 1159-66.

30. Roberge C, Einum S, Guderley H, Bernatchez L. Rapid parallel evolutionary changes of gene transcription profiles in farmed Atlantic salmon. Mol Ecol. 2006;15(1):9-20

31. Roberge C, Normandeau E, Einum S, Guderley H, Bernatchez L. Genetic consequences of interbreeding between farmed and wild Atlantic salmon: insights from the transcriptome. Mol Ecol. 2008;17(1):314-24.

32. Debes PV, Normandeau E, Fraser DJ, Bernatchez L, Hutchings JA. Differences in transcription levels among wild, domesticated, and hybrid Atlantic salmon (Salmo salar) from two environments. Mol Ecol. 2012;21(11):2574-87.

33. Bicskei B, Bron JE, Glover KA, Taggart JB. A comparison of gene transcription profiles of domesticated and wild Atlantic salmon (Salmo salar L.) at early life stages, reared under controlled conditions. BMC Genomics. 2014;15:884.

34. Bicskei B, Taggart JB, Glover KA, Bron JE. Comparing the transcriptomes of embryos from domesticated and wild Atlantic salmon (Salmo salar L.) stocks and examining factors that influence heritability of gene expression. Genet Sel Evol. 2016;48(1):1-16

35. Kittilsen S, Ellis T, Schjolden J, Braastad BO, Overli O. Determining stressresponsiveness in family groups of Atlantic salmon (Salmo salar) using noninvasive measures. Aquaculture. 2009;298(1-2):146-52.

36. Naslund J, Rosengren M, Del Villar D, Gansel L, Norrgard JR, Persson L, Winkowski JJ, Kvingedal E. Hatchery tank enrichment affects cortisol levels and shelter-seeking in Atlantic salmon (Salmo salar). Can J Fish Aquat Sci. 2013;70(4):585-90.

37. Krasnov A, Skugor S, Todorcevic M, Glover KA, Nilsen F. Gene expression in Atlantic salmon skin in response to infection with the parasitic copepod Lepeophtheirus salmonis, cortisol implant, and their combination. BMC Genomics. 2012;13.

38. Morrison DK. MAP kinase pathways. Cold Spring Harb Perspect Biol. 2012; 4(11):5.

39. Amaral AJ, Ferretti L, Megens HJ, Crooijmans R, Nie HS, Ramos-Onsins SE, Perez-Enciso M, Schook LB, Groenen MAM. Genome-wide footprints of pig domestication and selection revealed through massive parallel sequencing of pooled DNA. PLoS One. 2011;6(4):12.

40. Natt D, Rubin CJ, Wright D, Johnsson M, Belteky J, Andersson L, Jensen P. Heritable genome-wide variation of gene expression and promoter methylation between wild and domesticated chickens. BMC Genomics. 2012;13:12

41. Yang SB, Li XL, Li K, Fan B, Tang ZL. A genome-wide scan for signatures of selection in Chinese indigenous and commercial pig breeds. BMC Genet. 2014;15:9

42. Park W, Kim J, Kim HJ, Choi JY, Park JW, Cho HW, Kim BW, Park MH, Shin TS, Cho SK, et al. Investigation of De novo unique differentially expressed genes related to evolution in exercise response during domestication in thoroughbred race horses. PLoS One. 2014;9(3):12.

43. Moon S, Kim TH, Lee KT, Kwak W, Lee T, Lee SW, Kim MJ, Cho K, Kim N, Chung $\mathrm{WH}$, et al. A genome-wide scan for signatures of directional selection in domesticated pigs. BMC Genomics. 2015;16:12.

44. Wei HP, Yao YY, Zhang RW, Zhao XF, Du JL. Activity-induced long-term potentiation of excitatory synapses in developing Zebrafish retina in vivo. Neuron. 2012;75(3):479-89.

45. Castillo PE, Younts TJ, Chavez AE, Hashimotodani Y. Endocannabinoid signaling and synaptic function. Neuron. 2012;76(1):70-81.

46. Elphick MR. The evolution and comparative neurobiology of endocannabinoid signalling. Philos Trans Royal Soc B-Biol Sci. 2012; 367(1607):3201-15.

47. Zagorska A, Dulak J. HIF-1: the knowns and unknowns of hypoxia sensing. Acta Biochim Pol. 2004;51(3):563-85.

48. Martyniuk CJ, Crawford AB, Hogan NS, Trudeau VL. GABAergic modulation of the expression of genes involved in GABA synaptic transmission and stress in the hypothalamus and telencephalon of the female goldfish (Carassius auratus). J Neuroendocrinol. 2005;17(5):269-75.

49. Lillesaar C. The serotonergic system in fish. J Chem Neuroanat. 2011:41(4): 294-308.

50. Fleming IA, Einum S. Experimental tests of genetic divergence of farmed from wild Atlantic salmon due to domestication. ICES J Mar Sci. 1997;54(6): 1051-63.

51. Purves D, Augustine GJ, Fitzpatrick D, Katz LC, LaMantia AS, McNamara JO, Williams MS. Neuroscience. 2nd ed. Sunderland (MA): Sinauer Associates; 2001.

52. Tort L. Stress and immune modulation in fish. Dev Comp Immunol. 2011; 35(12):1366-75.

53. Nardocci G, Navarro C, Cortes PP, Imarai M, Montoya M, Valenzuela B, Jara P, Acuna-Castillo C, Fernandez R. Neuroendocrine mechanisms for immune system regulation during stress in fish. Fish Shellfish Immunology. 2014. 40(2):531-8

54. Glover KA, Bergh O, Rudra H, Skaala O. Juvenile growth and susceptibility to Aeromonas salmonicida subsp salmonicida in Atlantic salmon (Salmo salar L.) of farmed, hybrid and wild parentage. Aquaculture. 2006:254(1-4):72-81.

55. Thodesen J, Grisdale-Helland B, Helland SJ, Gjerde B. Feed intake, growth and feed utilization of offspring from wild and selected Atlantic salmon (Salmo salar). Aquaculture. 1999;180(3-4):237-46.

56. Fleming IA, Agustsson T, Finstad B, Johnsson Jl, Bjornsson BT. Effects of domestication on growth physiology and endocrinology of Atlantic salmon (Salmo salar). Can J Fish Aquat Sci. 2002;59(8):1323-30.

57. Fraser DJ, Houde ALS, Debes PV, O'Reilly P, Eddington JD, Hutchings JA Consequences of farmed-wild hybridization across divergent wild populations and multiple traits in salmon. Ecol Appl. 2010;20(4):935-53.

58. Fraser DJ, Minto C, Calvert AM, Eddington JD, Hutchings JA. Potential for domesticated-wild interbreeding to induce maladaptive phenology across multiple populations of wild Atlantic salmon (Salmo salar). Can J Fish Aquat Sci. 2010;67(11):1768-75.

59. Bougas B, Granier S, Audet C, Bernatchez L. The transcriptional landscape of cross-specific hybrids and its possible link with growth in brook Charr (Salvelinus fontinalis Mitchill). Genetics. 2010;186(1):97-U207. 
60. Renaut S, Nolte AW, Bernatchez L. Gene expression divergence and hybrid Misexpression between Lake whitefish species pairs (Coregonus spp. Salmonidae). Mol Biol Evol. 2009;26(4):925-36.

61. Green BS. Maternal effects in fish populations. In: Sims DW, editor. Advances in Marine Biology, Vol 54. San Diego: Elsevier Academic Press Inc; 2008. p. 1-105.

62. Einum S, Fleming IA. Maternal effects of egg size in brown trout (Salmo trutta): norms of reaction to environmental quality. Proc Royal Soc B-Biol Sci. 1999:266(1433):2095-100.

63. Einum S, Fleming IA. Selection against late emergence and small offspring in Atlantic salmon (Salmo salar). Evolution. 2000;54(2):628-39.

64. Houde ALS, Fraser DJ, O'Reilly P, Hutchings JA. Maternal and paternal effects on fitness correlates in outbred and inbred Atlantic salmon (Salmo salar). Can J Fish Aquat Sci. 2011;68(3):534-49.

65. Solberg MF, Fjelldal PG, Nilsen F, Glover KA. Hatching time and alevin growth prior to the onset of exogenous feeding in farmed, wild and hybrid Norwegian Atlantic salmon. PLoS One. 2014;9(12):e113697.

66. Wolf JB, Wade MJ. What are maternal effects (and what are they not)? Phil Trans Royal Soc B-Biol Sci. 2009;364(1520):1107-15.

67. Houde ALS, Black CA, Wilson CC, Pitcher TE, Neff BD. Genetic and maternal effects on juvenile survival and fitness-related traits in three populations of Atlantic salmon. Can J Fish Aquat Sci. 2015;72(5):751-8.

68. Bougas B, Audet $C$, Bernatchez $L$. The influence of parental effects on transcriptomic landscape during early development in brook charr (Salvelinus fontinalis, Mitchill). Heredity. 2013;110(5):484-91.

69. Besnier F, Glover KA, Lien S, Kent M, Hansen MM, Shen X, Skaala O. Identification of quantitative genetic components of fitness variation in farmed, hybrid and native salmon in the wild. Heredity. 2015;115(1):47-55.

70. Harvey A, Juleff G, Carvalho GR, Taylor MI, Solberg MF, Creer S, Dyrehovden $L$, Matre IH, Glover KA. Does density influence relative growth performance of farmed, wild, and F1 hybrid Atlantic salmon in semi-natural and hatchery common garden conditions? R Soc Open Sci. 2016;3:160152.

71. Lund RA, Hansen LP. Identification of wild and reared Atlantic salmon, Salmo salar L., using scale characters. Aquac Fish Manag. 1991;22:499-508.

72. Glover KA. Forensic identification of fish farm escapees: the Norwegian experience. Aquaculture Environ Interactions. 2010;1:1-10.

73. Glover KA, Skilbrei OT, Skaala O. Genetic assignment identifies farm of origin for Atlantic salmon Salmo salar escapees in a Norwegian fjord. ICES J Mar Sci. 2008;65(6):912-20.

74. Grimholt U, Drablos F, Jorgensen SM, Hoyheim B, Stet RJM. The major histocompatibility class I locus in Atlantic salmon (Salmo salar L.): polymorphism, linkage analysis and protein modelling. Immunogenetics. 2002;54(8):570-81.

75. Stet RJM, de Vries B, Mudde K, Hermsen T, van Heerwaarden J, Shum BP, Grimholt U. Unique haplotypes of co-segregating major histocompatibility class II a and class II B alleles in Atlantic salmon (Salmo salar) give rise to diverse class II genotypes. Immunogenetics. 2002;54(5):320-31.

76. Taggart JB. FAP: an exclusion-based parental assignment program with enhanced predictive functions. Mol Ecol Notes. 2007:7(3):412-5.

77. Tacchi L, Bickerdike R, Douglas A, Secombes CJ, Martin SAM. Transcriptomic responses to functional feeds in Atlantic salmon (Salmo salar). Fish Shellfish Immunol. 2011;31(5):704-15.

78. Glencross BD, De Santis C, Bicskei B, Taggart JB, Bron JE, Betancor MB, Tocher DR. A comparative analysis of the response of the hepatic transcriptome to dietary docosahexaenoic acid in Atlantic salmon (Salmo salar) post-smolts. BMC Genomics. 2015;16.

79. Morais S, Taggart JB, Guy DR, Bell JG, Tocher DR. Hepatic transcriptome analysis of inter-family variability in flesh $\mathrm{n}-3$ long-chain polyunsaturated fatty acid content in Atlantic salmon. BMC Genomics. 2012;13.

80. R Development Core Team: R: A Language and Environment for Statistical Computing. Vienna, Asutria; 2014. [http://www.R-project.org/].

81. Luo WJ, Friedman MS, Shedden K, Hankenson KD, Woolf PJ. GAGE: generally applicable gene set enrichment for pathway analysis. Bmc Bioinformatics. 2009;10:17.

82. Wettenhall JM, Smyth GK. limmaGUI: A graphical user interface for linear modeling of microarray data. Bioinformatics. 2004;20(18):3705-6.

83. Wickham H. ggplot2: elegant graphics for data analysis. New York. ISBN 978-3-319-24277-4: Springer-Veralag; 2016.

\section{Publisher's Note}

Springer Nature remains neutral with regard to jurisdictional claims in published maps and institutional affiliations.

\section{Ready to submit your research? Choose BMC and benefit from:}

- fast, convenient online submission

- thorough peer review by experienced researchers in your field

- rapid publication on acceptance

- support for research data, including large and complex data types

- gold Open Access which fosters wider collaboration and increased citations

- maximum visibility for your research: over $100 \mathrm{M}$ website views per year

At BMC, research is always in progress.

Learn more biomedcentral.com/submissions 